\title{
The Hands Off Ethiopia campaign, racial solidarities and intercolonial antifascism in South Asia (1935-36)
}

\author{
Arlena Buelli*(i) \\ Department of History and Cultures, University of Bologna, Piazza S. Giovanni in Monte, 2, 40124 Bologna, Italy \\ *Corresponding author. E-mail: arlena.buelli2@unibo.it
}

\begin{abstract}
The transnational campaign against the Italian invasion of the Ethiopian Empire (1936-36) has been widely acknowledged as a turning point for antiracist and anticolonial political organizing in the African continent and diaspora. This article seeks to reconstruct the South Asian participation in the Hands Off Ethiopia protests, to expand historical knowledge of the early-twentieth-century development of Afro-Asian solidarity ties as well as the intersection of anti-Fascist and anticolonial struggles. It examines the institutional responses to the invasion on the part of the Indian Legislative Assembly, and a series of demonstrations, local meetings and boycotts whose implications reverberated in the local and international press as well as in the concerns of British colonial authorities. As will be argued, this mobilization was fueled by feelings of racial solidarity, anti-imperialist analyses, anti-caste critiques, scriptural interpretations and religious universalisms.
\end{abstract}

In October 1935, when Fascist Italy launched a military campaign against the Ethiopian Empire, a public outrage spread around the African continent and within the diaspora ${ }^{1}$. The invasion was interpreted as a 'race war' waged by a White, imperialist and authoritarian regime on the last uncolonized African country, which had been revered as a pan-African and sacred motherland since the early nineteenth century ${ }^{2}$. In the following months, mass demonstrations took to the streets of Harlem, Cape Town, London, Kingston, Paris, Rio de Janeiro, Nairobi and many other cities. Transnational solidarity organizations and initiatives proliferated and tens of thousands of dollars were raised to send medical aid to the frontlines. The Ethiopian cause became 'the story of the year for the black press' ${ }^{3}$, and dozens of new antiracist and anticolonial propaganda organs were created. Colonial citizens from every corner of the British Empire petitioned King Henry V to volunteer in defence of the endangered African empire. In Port of Spain, Durban, Lüderitz Bay, Bône, Hamburg, Marseille, Seattle and San Francisco, Black dockworkers refused to load Italian ships, and a boycott of Italian business spread from Egypt to Spanish Morocco. This global mobilization contributed to radicalizing

\footnotetext{
${ }^{1}$ In this article, I use the term 'diaspora' to reassume the early-twentieth-century growing 'cultural and political coordination of the interests of peoples of African descent around the world', in accordance with the recent scholarship on African, AfricanAmerican and Afro-Latinx anticolonial and antiracist struggles. A landmark definition of this use has been provided by Brent Hayes Edwards, 'The Uses of Diaspora', Social Text 66, no. 19 (2001): 45-73.

${ }^{2}$ Getachew Metaferia, 'The Ethiopian Connection to the pan-African Movement', Journal of Third World Studies 12, no. 2 (1995): 300-25; Charles R. Price, 'Cleave to the Black: Expressions of Ethiopianism in Jamaica', New West Indian Guide 77 (2003): 31-64; G. Bonacci, 'From Pan-Africanism to Rastafari: African American and Caribbean "Returns" to Ethiopia', in Understanding Contemporary Ethiopia, eds. G. Prunier and E. Ficquet (London: Hurst \& Co, 2015), 147-56.

${ }^{3} J o h n$ Munro, 'Ethiopia Stretches Forth Across the Atlantic: African American Anticolonialism during the Interwar Period', Left History 13, no. 2 (2008): 47.

( ) The Author(s), 2022. Published by Cambridge University Press. This is an Open Access article, distributed under the terms of the Creative Commons Attribution licence (http://creativecommons.org/licenses/by/4.0/), which permits unrestricted re-use, distribution and reproduction, provided the original article is properly cited.
} 
antiracist and anticolonial feelings almost everywhere and fuelled the expansion of already existing organizational and information networks. Therefore, historians of the twentieth century came to acknowledge it as a turning point for Black liberation struggles, as extensively attested by more than fifty years of scholarship ${ }^{4}$. Relying on an enlarged pool of archival and press sources, this article argues that protests articulated in analogous antiracist and anticolonial terms also broke out across South Asia ${ }^{5}$.

This South Asian support for antiracist and anticolonial causes promoted by Africans and people of African descent was not confined to the two years of invasion itself. On the contrary, recent historiography has demonstrated that it followed from decades of growing mutual interest, intellectual exchange and political collaboration. In fact, the increasing mobility and interconnectedness characterizing the interwar years brought otherwise distant actors who already shared experiences of subordination and exploitation into contact ${ }^{6}$. The tightening political repression following two decades of revolutionary agitation in Bengal and Punjab as well as the global impact of the Great Depression forced many radicals into exile, with American, British and Canadian urban centres as main destinations ${ }^{7}$. Living abroad, South Asian aliens confronted even more deeply the 'global dimension of the color line' and its increasingly paranoid surveillance by means of xenophobic violence and exclusionary citizenship laws ${ }^{8}$. Moreover, it was transoceanic émigré networks who comprised the social base and logistical infrastructure of several anticolonial and anti-imperialist movements, the best known of which was the Ghadar Party (1913-48). The 'eclectic array of strategic contacts'9 established by these movements included antiracist organizations populated by people of African descent and they engaged in dialogue and collaboration in settings as diverse as

\footnotetext{
${ }^{4}$ To cite only a few significant contributions: Robert G. Weisbord, 'British West Indian Reaction to the Italian-Ethiopian War: An Episode in Pan-Africanism', Caribbean Studies 10, no. 1 (1970): 34-41; S.K.B. Asante, Pan-African Protest, West Africa and the Italo-Ethiopian Crisis, 1934-1941 (London: Longman, 1977); William R. Scott, 'Black Nationalism and the Italo-Ethiopian Conflict 1934-1936', The Journal of Negro History 63 (1978): 118-34; Edmund L. Drago, 'American Blacks and Italy's Invasion of Ethiopia', Negro History Bulletin 41 (1978): 883; Cedric Robinson, 'The African diaspora and the Italo-Ethiopian crisis', Race and Class 27 (1985): 51-65; Fikru Gebrekidan, 'In Defense of Ethiopia: A Comparative Assessment of Caribbean and African American Anti-Fascist Protests, 1935-1941', Northeast African Studies 2, no. 1 (1995): 145-73; Joseph Fronczak, 'Local People's Global Politics: A Transnational History of the Hands Off Ethiopia Movement of 1935', Diplomatic History 39, no. 2 (2015): 245-74.

${ }^{5}$ Primary sources for this article were collected mainly from the India Office Records archives and include police reports, governmental meeting minutes, and private correspondence as well as a selection of international (British, African-American, Indian) press materials.

${ }^{6}$ Ali Raza, Franziska Roy and Benjamin Zachariah depicted this period as a South Asian 'internationalist moment'. The Internationalist Moment: South Asia, Worlds, and World Views, 1917-39 (Delhi: Sage, 2015); Sugata Bose and Kris Manjapra, eds., Cosmopolitan Thought Zones: South Asia and the Global Circulation of Ideas (London: Palgrave Macmillan, 2010).

${ }^{7}$ Peter Heehs, The Bomb in Bengal: The Rise of Revolutionary Terrorism in India, 1900-1910 (Oxford: Oxford University Press, 1993); Dietmar Rothermund, The Global Impact of the Great Depression, 1929-1939 (London: Routledge, 1996), 87-95; K.A. Manikumar, A Colonial Economy in the Great Depression, Madras (1929-1937) (Himayatnagar: Orient Longman, 2003).

${ }^{8}$ Marilyn Lake and Henry Reynolds, Drawing the Global Colour Line: White Men's Countries and the International Challenge of Racial Equality (Cambridge: Cambridge University Press, 2008). Vivek Bald gives insightful depictions of these experiences under the concept of 'overlapping diasporas': 'Overlapping Diasporas, Multiracial Lives: South Asian Muslims in U.S. Communities of Color, 1880-1950', Souls 8, no. 4 (2006): 3-18; 'Lost in the city: Spaces and stories of South Asian New York, 1917-1965', South Asian Popular Culture 5, no.1 (2007): 59-76; 'Selling the East in the American South Bengali Muslim Peddlers in New Orleans and Beyond, 1880-1920', in Asian Americans in Dixie: Race and Migration in the South, ed. J. Desai (Chicago: University of Illinois Press, 2013), 33-53.

${ }^{9}$ Maia Ramnath, 'Two Revolutions: The Ghadar Movement and India's Radical Diaspora, 1913-1918', Radical History Review 92, no. 1 (2005): 8.
} 
the Americas $^{10}$ and among migrant communities in Europe ${ }^{11}$ and the Indian Ocean ${ }^{12}$. Furthermore, the Communist International's concern with the 'national and colonial question' provided institutional channels, resources and sites of encounter to Black and Asian leaders ${ }^{13}$. One particularly noteworthy such site was the League Against Imperialism (LAI, 1927-37) whose inaugural meeting in Brussels brought together nationalists, communists and socialists from over thirty colonies and protectorates, including Indian National Congress party (INC, 1885-) leader Jawaharlal Nehru ${ }^{14}$.

Research has underlined that the interweaving of personal ties and friendships among political organizers, politically engaged intellectuals and religious figures was an important driver behind the development of Afro-Indian solidarity. In this respect, historian Nico Slate collected evidence of intense exchanges of correspondence, declarations of support and invitations (to tour the respective motherlands, give public speeches and lectures, and participate to meetings) under the definition of 'race diplomacy'15. The printed word also played a key role: the transnational circulation of Black-edited newspapers and periodicals reached South Asian radical circles ${ }^{16}$; in turn, Indian nationalists actively contributed to this militant press and clipped and translated articles on the 'race problem' for their own organs ${ }^{17}$. African-American political literature and informative travel books recounting segregation and anti-Black racism around the world also circulated in Indian native languages ${ }^{18}$. The Pan-African Congresses provided another forum for

\footnotetext{
${ }^{10}$ Gerald Horne, The End of Empires: African Americans and India (Philadelphia: Temple University Press, 2008); Sudarshan Kapur, Raising Up A Prophet: The African-American Encounter With Gandhi (Boston: Beacon Press, 1992); M. Iyengar, 'Afro-Asian-Caribbean Connections in Transnational Circulation: The Harlem Ashram as Chronotope', in Afro-Asian Connections in Latin America and the Caribbean, ed. L. M. Ossa and D. Lee-DiStefano (Lanham: Lexington Books, 2019), 61-88; Kelvin Singh, 'Adrian Cola Rienzi and the Labour Movement in Trinidad (1925-44)', The Journal of Caribbean History 1, no. 3-4 (1982): 10-35; Sahadeo Basdeo, 'Indian Participation in Labour Politics in Trinidad, 19191939', Caribbean Quarterly 32, no. 3-4 (1986): 50-64.

${ }^{11}$ London-based examples are the Coloured Men's Institute founded by the Ceylonese Kamal A. Chunchie and South Asian participation in the League of Coloured People. Rozina Visram, 'Kamal A. Chunchie of the Coloured Men's Institute: The man and the legend', Immigrants \& Minorities 18, no. 1 (1999): 29-48; David A. Vaughan, Negro Victory: The Life Story of Dr. Harold Moody (London: Independent Press, 1950), 65-7.

${ }^{12}$ Regarding interethnic solidarity with Indian and Kikuyu anti-settler politics in colonial Kenya, see Sana Aiyar, 'Empire, Race and the Indians in Colonial Kenya's Contested Public Political Sphere, 1919-1923', Africa 81, no. 1 (2011): 132-54.

${ }^{13} \mathrm{~K}$. Manjapra, Communist Internationalism and Transcolonial Recognition in Bose and Manjapra, Cosmopolitan Thought Zones, 167.

${ }^{14}$ Michele Louro, Carolien Stolte, Heather Streets-Salter and Sana Tannoury-Karam, eds., The League Against Imperialism: Lives and Afterlives (Leiden: Leiden University Press, 2020); Michele Louro, Comrades against Imperialism: Nehru, India, and Interwar Internationalism (Cambridge: Cambridge University Press, 2018).

${ }^{15}$ Nico Slate, Colored Cosmopolitanism: The Shared Struggle for Freedom in the United States and India (Cambridge: Cambridge University Press, 2012).

${ }^{16}$ On the development of these transnational print circuits, see L. James, 'Transatlantic Passages: Black Identity Construction in West African and West Indian Newspapers, 1935-1950', in African Print Cultures: Newspapers and Their Publics in the Twentieth Century, eds. D. Peterson, E. Hunter and S. Newell (Ann Arbor: University of Michigan Press, 2016), 49-74; L. Putnam, Circum-Atlantic Print Circuits and Internationalism from the Peripheries in the Interwar Era, in Print Culture Histories beyond the Metropolis, eds. J. Connolly et al. (Toronto: University of Toronto Press, 2016).

${ }^{17}$ Catherine Innes, A History of Black and Asian writing in Britain, 1700-2000 (Cambridge: Cambridge University Press, 2002).

${ }^{18}$ As indicated by the correspondence between Indian intellectuals and educators and African-American antiracist activists such as Booker T. Washington and W. E. B. Du Bois, volumes translated into Hindi, Marathi and Telegu included the classics Up From Slavery (1901), Character Building (1902), The Souls of Black Folk (1903) and The Negro (1915). As scholars have noted, Afro-Asian reciprocal interest often focused on issues of minority education and 'upliftment'. Among the travel book reflecting on the global color line, the most frequently cited was Lala Lajpat Rai's The United States of America: A Hindu's Impression (1916), published in English in Calcutta. Louis Harlan, Booker T. Washington: The Wizard of Tuskegee, 1901-1915 (New York: Oxford University Press, 1982), 277-8; Horne, The End of Empires, 84; M. Iyengar, 'Colored Cosmopolitanism and the Classroom: Educational Connections Between African Americans and South Asians', in Encyclopedia of Educational Philosophy and Theory, ed. M. Peters (Singapore: Springer, 2015), 1-6; and Babli Sinha, 'Dissensus, education and Lala Lajpat Rai's encounter with W.E.B. Du Bois', South Asian History and Culture 6, no. 4 (2015): 462-76.
} 
discussing race and antiracism: intermittently held in European, American and African cities beginning in $1919^{19}$, these events included Indian participants beginning with the Second Congress (Paris, 1921) where the Parsi delegate for the Communist Party of Great Britain Shapurji Saklatvala delivered a speech on 'the position of India, and said that the people of India were proud to be part of the coloured world ${ }^{20}$.

These ties of solidarity generally shared a conceptual framework, focused on delegitimizing and overthrowing 'global white supremacy'. Racial identification played an important part in this 'rhetorical construction of potential alliance': according to one of its more energetic proponents, the African-American intellectual W.E.B. Du Bois, 'the problem of the Indians can never be simply a problem of autonomy in the British commonwealth of nations', since 'they must always stand as representatives of the coloured races, of the yellow and black peoples as well as the brown - of the majority of mankind ${ }^{21}$. This vision appealed to a variety of preAfrocentric narratives according to which the dark-skinned 'Dravidian natives' of the Indian subcontinent (then a 'colored country') represented the origins of Black history ${ }^{22}$. Nevertheless, such appeals were received in divergent ways and did not resonate well with the understanding of anti-imperialism shared by most Indian nationalist elites-to-come. Indeed, transnationally shared assumptions about Indo-European superiority were sometimes used to position the subcontinent in a 'racial/spatial order' located far from the coloured world ${ }^{23}$. At the same time, both Black and Dalit activists pointed out the similarities between the history of slavery and Jim Crow, and upper varnas domination and untouchability practices. As will be seen in more detail, these race-caste political analogies, especially popular in the context of anti-caste and egalitarian struggles in Southern India, contributed to the viability of early Afro-Indian solidarity ties ${ }^{24}$.

Either way, the Indians who condemned the Italian attack on Ethiopia and claimed sympathy with its people felt, or at least asserted, a commonality of interests, future expectations and even ancestry with Ethiopians. As this article will argue, these commonalities were based on shared anti-imperialist and anticolonial analyses, scriptural interpretations, and, above all, racial kinship. I reconstruct this part of the story by examining two arenas: institutional responses to the invasion on the part of the Indian Legislative Assembly, and a series of demonstrations, local meetings and boycotts whose implications reverberated in the local and international press as well as the concerns of British colonial authorities. I highlight the widespread and multileveled character of these protests, attempting to show how they represented a case of anticolonial internationalism 'from below'. Also, I pay special attention to instances of interplay between these initiatives and anticaste mobilization in Southern India as well as the participation of Indian Muslim protestors.

\footnotetext{
${ }^{19}$ Hakim Adi, Pan-Africanism: A History (London: Bloomsbury, 2018), 43-60.

${ }^{20}$ 'Pan-African Congress', Richmond Times, 3 September 1921.

${ }^{21}$ Special Collections and University Archives, University of Massachusetts Amherst Libraries, W. E. B. Du Bois Papers [UMAL/MS 312], W.E.B. Du Bois, Indians and American Negroes, March 1936, typed draft. See Daniel Immerwahr, 'Caste or colony? Indianizing race in the United States', Modern Intellectual History 4, no. 2 (2007): 275; Biman Basu, 'Figurations of India and the Transnational in W.E.B. Du Bois', Diaspora: A Journal of Transnational Studies 10 (2001): 228.

${ }^{22}$ Bill V. Mullen, 'Du Bois, Dark Princess, and the Afro-Asian International', positions: east asia cultures critique 11, no. 1 (2003): 223; Id., Afro-Orientalism (Minneapolis: University of Minnesota Press, 2004), xi-72.

${ }^{23}$ S. Krishna, A postcolonial racial/spatial order: Gandhi, Ambedkar, and the construction of the international, in Race and Racism in International Relations: Confronting the Global Colour Line, eds. A. Anievas, N. Manchanda and R. Shilliam (London: Routledge, 2014), 139-56; Subho Basu, 'The Dialectics of Resistance: Colonial Geography, Bengali Literati and the Racial Mapping of Indian Identity', Modern Asian Studies 44, no. 1 (2010): 53-79.

${ }^{24} J a n e t$ Neary and Tanya Agathocleous recently analysed the practice of 'Afro-Asian cross-referencing' to enrich existing reconstructions of the mid-to-late nineteenth century emergence of "caste" as a key concept in racial uplift literature in the US, and of the specular use of antiracist and anti-slavery rhetoric in anti-caste movements in colonial India. 'Before Bandung: Afro-Asian Cross-referencing and Comparative Racialization', Journal of Social History 54, no. 2 (2020): 599-622.
} 
Furthermore, this reconstruction hopes to contribute to recent scholarly efforts to address interwar anti-Fascism in a global and non-Eurocentric perspective ${ }^{25}$. Indeed, for non-White public opinions the Hands Off Ethiopia campaign also represented an unprecedented occasion for knowledge production and discussion about forms of Fascism. Many participants framed manifestations of Fascism as virulent combinations of racist principles and imperialist ambitions the spread of which had to be opposed, although without sidelining colonial liberation $^{26}$. As the article will evidence, these publics viewed as fully fledged Fascist not only the Italian regime's international dissemination of racist propaganda, but also the segregation laws it imposed in East Africa and the illegal means of warfare it employed ${ }^{27}$. In fact, they also attacked the appeasement policies pursued by other imperial European powers and the League of Nations' hypocritical management of the crisis as 'fascist-imperialist' or 'colonial-fascist' ${ }^{\prime 2}$. Finally, tracing the connections between South Asian and other anti-Fascist mobilizations and intercolonial debates also means engaging with the contemporary literature on global fascism ${ }^{29}$. On this side, this article attempts to round out historical accounts of Indian collaboration, dialogue and participation in Fascist and Nazi organizations $\mathrm{s}^{30}$ and the emergence of groups in India 'borrowing and adapting' from the ideological and practical repertoire of European fascisms ${ }^{31}$ by presenting additional sides of the story.

\section{'Indian opinion' on the 'League of Robbers': institutional responses and antiracist solidarity}

As the establishment of the Fascist regime in Italy brought colonial politics to the centre of the agenda once again, a growing 'imperial anxiety' manifested itself as outspoken frustration with international treaties ${ }^{32}$. Benito Mussolini had repeatedly displayed his aspirations in relation to Ethiopian territories since at least 1925, until an alleged encroachment on the border with Italian Somaliland (5 December 1934) offered him a pretext to invade (3 October 1935) ${ }^{33}$. This move was facilitated by British and French governments' attitudes of appeasement and

\footnotetext{
${ }^{25}$ Kasper Braskén, Nigel Copsey and David Featherstone, eds., Anti-Fascism in a Global Perspective: Transnational Networks, Exile Communities, and Radical Internationalism (London: Routledge, 2020); Hugo García, 'Transnational History: A New Paradigm for Anti-Fascist Studies?', Contemporary European History 25, no. 4 (2016): 563-72.

${ }^{26}$ Tom Buchanan, 'The Dark Millions in the Colonies are Unavenged: Anti-Fascism and Anti-Imperialism in the 1930s', Contemporary European History 25, no. 4 (2016): 645-65; Clayton Vaughn-Roberson, 'Grassroots Anti-Fascism: Ethiopia and the Transnational Origins of the National Negro Congress in Philadelphia, 1935-1936', American Communist History 17, no. 1 (2018): 4-15.

${ }^{27}$ Nicola Labanca, La Guerra d'Etiopia, 1935-1941 (Bologna: Il Mulino, 2015), 84-94; Dominik Schaller and Jurgen Zimmerer, 'Settlers, imperialism, genocide: Seeing the global without ignoring the local', Journal of Genocide Research 10, no. 2 (2008): 191-9; Marc Matera and Susan Kent, The Global 1930s: The International Decade (London: Routledge, 2017), 45-6.

${ }^{28}$ Regarding these formulations in anticolonial circles, see Priyamvada Gopal, Insurgent Empire: Anticolonial Resistance and British Dissent (London: Verso Books, 2019), 343-63; Leslie James, George Padmore and Decolonization from Below: PanAfricanism, the Cold War, and the End of Empire (New York: Palgrave Macmillan, 2015), 43-6.

${ }^{29}$ For an overview of recent contributions and problems, see Tim Jacoby, 'Global fascism: geography, timing, support, and strategy', Journal of Global History 11 (2016): 451-72.

${ }^{30}$ Marzia Casolari, In the Shadow of the Swastika: The Relationships between Indian Radical Nationalism, Italian Fascism and Nazism (London: Routledge, 2020); Maria Framke, Delhi-Rom-Berlin: Die indische Wahrnehmung von Faschismus und Nationalsozialismus, 1922-1939 (Darmstadt: WBG, 2013).

${ }^{31}$ Benjamin Zachariah, 'A Voluntary Gleichschaltung? Perspectives from India towards a non-Eurocentric Understanding of Fascism', Transcultural Studies 2 (2014): 64.

${ }^{32}$ N. Labanca, 'Studies and Research on Fascist Colonialism, 1922-1935', in A Place in the Sun: Africa in Italian Colonial Culture from Post-Unification to the Present, ed. P. Palumbo (Berkeley: University of California Press, 2003), 37-61.

${ }^{33}$ Giorgio Rochat, Militari e politici nella preparazione della campagna d'Etiopia: Studio e documenti 1932-1936 (Milano: Franco Angeli, 1971).
} 
the indulgent mediation of the League of Nations, as the latter did nothing more than belatedly and ineffectively sanction Italy's illegitimate aggression in November $1935^{34}$.

The Indian Legislative Assembly ${ }^{35}$ began to discuss the fate of Ethiopian independence in early September 1935, one month before the Fascist regime launched its campaign. This discussion was triggered by protests against the precautionary move to send an Indian Army contingent to Addis Ababa to protect British citizens and their property. The move was denounced as the umpteenth seizure of Indian men and resources for 'Imperial interests' without having consulted 'Indian opinion'36. Building on this initial episode, Indian representatives began to contest 'the foreign policy of the British Government' more generally, accusing it of not having taken a clear stance in favour of the endangered African empire. According to Punjabi Sikh leader Sardar Mandal Singh, Indian opinion instead held 'that if and when the occasion arises to help Indian nationals in Abyssinia or to defend poor Abyssinia against European capitalism, the Indian Army should be allowed to go there and help those people'. This recommendation, subsequently echoed by the press and in later Assembly debates ${ }^{37}$, was reiterated by Krishna Kant Malaviya ${ }^{38}$ :

If we had any voice in the affairs of our own country, if our opinion was asked as to what was the right thing to do, we would say that our opinion is, as representatives of this country, and a member of the League of Nations, that we want to go to help Abyssinia and we want to go to war with Italy in order to show her that she has no right to invade Abyssinia. [...]

I feel [...] that the Government of India should have forced the hands of His Majesty's Government also to enter the war, instead of wavering, and help the Abyssinian Government. It is said, Sir, that we are the original members of the League of Nations, which

\footnotetext{
${ }^{34}$ Richard Davis, The Collapse of the Hoare-Laval Plan, in Anglo-French Relations Before the Second World War: Appeasement and Crisis, ed. Id. (London: Palgrave Macmillan, 2001), 107-14; Francesco Lefebvre D'Ovidio, La questione etiopica nei negoziati italo-franco-britannici del 1935, Roma, Epj, 2000; George W. Baer, 'Sanctions and Security: The League of Nations and the Italian-Ethiopian War, 1935-1936', International Organization 27, no. 2 (1973): 165-79.

${ }^{35} \mathrm{~A}$ body of Indian elected representatives instituted in 1921 as the Imperial Legislative Council's lower house. Although for purposes of linearity I have begun the narrative with these claims being asserted on the Assembly floor, it is important to bear in mind that the Assembly's stance represented only one facet of public opinion - due to its strictly limited electoral viability and decision-making powers - and not representative of the entire range of claims and sentiments prevailing across the wider grassroots mobilizations that will be addressed below.

${ }^{36}$ British Library, India Office Records, Political and Secret Department Records, Political (External) Collection [IOR/L/PS/ 12/1521], Official report of the Indian Legislative Assembly debate, 3 September 1935. Composed of 20 Sikh Sepoys and 130 officers and men from the Fourth and Fifth Punjab Regiment, the Indian Legation Guard remained in the Ethiopian capital until November 1936. In line with long-running critiques expressed in South Asian anticolonial circles about the protection pledged to the British Empire by Sikh soldiers, the Indian, British and African-American press covered the vicissitudes of the Legation Guard with references to the Indian soldiers' 'state of depression'. 'British Legation in Addis Ababa', Times, 7 November 1936; 'Ethiopians Eye India - Troops of Britain', Chicago Defender, 14 September 1935; 'The Council of State: Indian Troops in Abyssinia', Indian Annual Register, July-December 1935. Later, a royal acknowledgement of the Guard's service was released to the Indian press, praising its 'utility' with respect to native 'public opinion'. IOR/L/PS/12/ 1521, FO to Information Office, 24 December 1936; J.C. Watson, India Office Political Department (IPD), to G.H. Thompson, Foreign Office (FO), 16 November 1936.

${ }^{37}$ 'The Legislative Assembly: Indian Troops for Abyssinia', Indian Annual Register, July-December 1935; W.F. Charter, 'Abyssinia Contingent [Detachment: 5th Battalion (Pathans)- 14th Punjab Regiment]', Journal of the United Service Institution of India, 67, October, 1937.

${ }^{38}$ Ambiguously, Malaviya was a former militant of the Hindu Mahasabha (whose virulently nationalist and racist ideology have been documented along with its leaders' ties to Fascist Italy and Nazi Germany) who had entered the Indian Legislatures on the Liberal Party ticket in the 1920s. Richard Gordon, 'The Hindu Mahasabha and the Indian National Congress, 1915 to 1926', Modern Asian Studies 9, no. 2 (1975): 164, 190; C. Jaffrelot, 'The ideas of the Hindu race in the writings of Hindu nationalist ideologues in the 1920s and 1930s', in The Concept of Race in South Asia, ed. P. Robb (Delhi: Oxford University Press, 1995), 327-54.
} 
I have always called 'League of Robbers', and, as such, I think we have a right to say that we should go to war to protect a weak nation, to prevent a war of aggression ${ }^{39}$.

Despite receiving evasive responses from the government, the Assembly repeatedly spoke out about 'Indian feelings regarding Italy's Conquest of Abyssinia' ${ }^{40}$ after the capture of Addis Ababa and proclamation of the Fascist Empire (5 May 1936). In particular, its Indian members once again expressed themselves 'very strongly on the attitude of Italy towards Abyssinia and on the impotence of the League of Nations' following 'the speech made by the ex-Emperor of Abyssinia' to its Genevan headquarters (30 June 1936) ${ }^{41}$. The 'attention of Government' was again 'drawn' to the speech by Sardar Sant Singh ${ }^{42}$. In the previous months, Haile Selassie's final plea for support had received sensational coverage in the international anticolonial and antiracist press, especially his denunciation of the illegal means of warfare deployed by Fascist Italy. The Indian Assembly went on to debate these means, including poison gas used for terrorist attacks, bombing raids on Red Cross International Committee field hospitals and ambulances, and deportations and arbitrary massacres ${ }^{43}$ at its 4 September 1936 session $^{44}$. In his extensive account, historian Richard Pankhurst observes that 'Fascist atrocities, though widely condemned by individuals and organizations, passed officially unnoticed by the League of Nations ${ }^{35}$. After all, Italy's conduct was in line with the bloody standards of European colonial warfare, including chemical weapon use, already characterizing the Spanish campaigns in Morocco and British management of anticolonial insurgencies in India, the Middle East and the West Indies ${ }^{46}$. For Britain, having itself 'established the principle of air bombardment [...] to colonial necessities' and put it into practice multiple times and 'quite recently', it would not have been opportune to protest similar means employed by another European power ${ }^{47}$.

Viewed from colonial eyes, the League's final decision to lift all sanctions against Italy after Haile Selassie's speech confirmed that the international organization was instrumental to maintaining imperialist rule and its balance of interests. It likewise bore out Du Bois' prediction that 'the result of Italy's venture must inevitably tend to destroy in India whatever faith there is in the justice of white Europe ${ }^{48}$. At the same time, Indian representatives continued to assert their rights as 'independent' and paying members of these fraudulent White institutions in service of their

\footnotetext{
${ }^{39} \mathrm{IOR} / \mathrm{L} / \mathrm{PS} / 12 / 1521$, Indian Legislative Assembly debate, 3 September 1935.

${ }^{40} \mathrm{IOR} / \mathrm{L} / \mathrm{PS} / 12 / 1536$, Indian Legislative Assembly debate, 4 September 1936.

${ }^{41} \mathrm{IOR} / \mathrm{L} / \mathrm{PS} / 12 / 1536$, Indian Legislative Assembly debate, 11 September 1936.

${ }^{42} \mathrm{IOR} / \mathrm{L} / \mathrm{PS} / 12 / 1536$, Indian Legislative Assembly debate, 16 September 1936. Significantly, it was Singh who went on to lead the first diplomatic mission to Ethiopia after Indian independence. Leta Belayneh and Girma Belayneh, 'Economic relations of Ethiopia and India: Trade and agricultural investments after 1991', African Journal of Political Science and International Relations 11, no. 8 (2017): 211.

${ }^{43}$ A. Sbacchi, 'Poison Gas and Atrocities in the Italo-Ethiopian War (1935-1936)', in Italian Colonialism, eds. R. Ben-Ghiat and M. Fuller (London: Palgrave Macmillan, 2005), 47-56; Angelo Del Boca, I gas di Mussolini. Il fascismo e la guerra d'Etiopia (Roma: Editori Riuniti, 1996); Neve Gordon and Nicola Perugini, Human Shields: A History of People in the Line of Fire (Berkeley: University of California Press, 2020), 60-70; Paolo Borruso, Debre Libanos 1937: Il più grave crimine di guerra dell'Italia (Roma-Bari: Laterza, 2020).

${ }^{44} \mathrm{IOR} / \mathrm{L} / \mathrm{PS} / 12 / 1536$, Indian Legislative Assembly debate, 4 September 1936.

${ }^{45}$ Richard Pankhurst, 'Italian Fascist War Crimes in Ethiopia: A History of Their Discussion, from the League of Nations to the United Nations (1936-1949)', Northeast African Studies 6, no. 1-2 (1999): 83.

${ }^{46}$ Sebastian Balfour, Deadly Embrace. Morocco and The Road to The Spanish Civil War (Oxford: Oxford University Press, 2002); Erik Linstrum, 'Domesticating Chemical Weapons: Tear Gas and the Militarization of Policing in the British Imperial World, 1919-1981', The Journal of Modern History 91, no. 3 (2019): 557-85.

${ }^{47}$ This evidence was made explicit by the former (and first) secretary of the League of Nations, James Eric Drummond (at the time British Ambassador in Rome) in a letter to Minister of Foreign Affairs Anthony Eden. After listing a series of antecedents that made the Fascist war practices unexceptional, Drummond concluded 'With these facts before them the British must be silent at Geneva. Here again Italy is only following England's example'. IOR/L/PS/12/1521, from Eric J. Drummond to Min. Anthony Eden, 18 March 1936.

${ }^{48}$ W.E.B. Du Bois, 'Inter-Racial Implications of the Ethiopian Crisis: A Negro View', Foreign Affairs 14, no. 1 (1935): 89.
} 
own national and transnational ends' by stating that the Government of India, contributing as much to its budget as Italy did, had a duty 'to interfere with the working of the League if they find it against the interests of India as a whole ${ }^{49}$. Nevertheless, in debates the prevailing interpretation of the Italo-Ethiopian conflict was that of a supremacist act of aggression, a race war 'intimately' concerning all 'the non-white races ${ }^{50}$. Beginning with the Assembly's very first discussions, the observation that 'In our own country, we [Indian natives] are not entitled to express our opinions' was explained with the reminder that 'We are a subject race'. Krishna Kant Malaviya replied to this by saying 'I know that we are a subject race, and that is why I want that Abyssinia should not be subjugated'51.

As evidenced by the above-mentioned literature on early-century Afro-Asian solidarities, it was not at all obvious to Indians, and especially upper-caste nationalist leaders, that they shared common interests, future expectations and even racial kinship Black Africans. Nevertheless, it has been argued that the move to impose segregation and anti-miscegenation laws in Italian East Africa $(1936,1937)$, also targeting Indian residents and defining them as 'moral half-castes 52 , effectively disqualified 'Rome as a sponsor of Asian anti-imperialism' - an image that Mussolini attempted to project, as will be discussed below. This development instead triggered 'a strong sense of solidarity with Abyssinia' in India ${ }^{53}$. Furthermore, the regime's international propaganda set out to legitimize its war of conquest by asserting the racial and civilizational inferiority of the African enemy, depicting Ethiopians as 'backward' and 'barbaric' and, as such, unsuited to statehood and sovereignty ${ }^{54}$. These racist overtones did not fall on deaf ears in India, as suggested by the final declaration of solidarity delivered by the Orissan Congressman Nilakantha Das:

In spite of all our European dresses and dinners and other paraphernalia, all the words and phrases of the European constitution sticking all around us like peacocks' feathers, we are what we are. We are among the black and brown races, and we have heard what Mussolini said the other day... [interruption from the government benches]

[...] What I mean to say is this. Our sympathies naturally go towards Abyssinia, and it may be that when Italy is to be fought by people who are in charge of our troops . . ${ }^{55}$

This comment likely refers to an interview Mussolini gave the French journalist Henry de Kerillis (20 July 1935) in which the Italian dictator defined Ethiopia as the testing grounds 'to discover if Europe is still worthy of fulfilling the civilizing mission that has made it great for several centuries'

${ }^{49} \mathrm{IOR} / \mathrm{L} / \mathrm{PS} / 12 / 1536$, Indian Legislative Assembly debate, 16 September 1936; Matera, Kent, The Global 1930s, 5. This twofold strategy was enacted by Richard Drayton with respect to Caribbean political actors over the same period. See 'Commonwealth History From Below? Caribbean national, federal and Pan-African renegotiations of the Empire project, c. 1880-1950', in Commonwealth History in the Twenty-First Century, eds. R. Drayton and S. Dubow (London: Palgrave Macmillan, 2020), 41-60.

${ }^{50}$ The African-American weekly Chicago Defender so quoted in 'the Hindu press', 'India Sees Dispute as Fundamentally Racial', Chicago Defender, 28 September 1935.

${ }^{51} \mathrm{IOR} / \mathrm{L} / \mathrm{PS} / 12 / 1521$, Indian Legislative Assembly debate, 3 September 1935.

${ }^{52}$ E.M. Robertson, 'Race as a Factor in Mussolini's Policy in Africa and Europe', Journal of Contemporary History 23 (1988): 51. For instance, the Calcutta Statesman and the Madras Hindu condemned these 'ridiculous' and 'discriminatory regulations', including 'denial to Indians of access to the European section of the post offices, restaurants and cinemas', as well as transports, as racist 'arrogance'. Cit. in 'Indians Suffer in Abyssinia', New Times and Ethiopia News, 7 November 1939.

${ }^{53}$ Carolien Stolte, 'Orienting India: Interwar Internationalism in an Asian Inflection, 1917-1937' (PhD diss., Leiden University, Leiden, 2013), 104, 115; Giulia Barrera, 'Mussolini's colonial race laws and state-settler relations in Africa Orientale Italiana (1935-41)', Journal of Modern Italian Studies 8, no. 3 (2003), 425-43.

${ }^{54}$ Gino Satta, 'Civiltà di Roma e barbarie abissina. La propaganda antischiavista e la guerra d'Etiopia', Parolechiave, no. 1 (2016): 67-76; Jean Allain, 'Slavery and the League of Nations: Ethiopia as a Civilised Nation', Journal of the History of International Law 8, no. 2 (2006): 213-44; Robbie Shilliam, 'Intervention and colonial-modernity: Decolonising the Italy/ Ethiopia conflict through Psalms 68:31', Review of International Studies 39, no. 5 (2013): 1131.

${ }^{55} \mathrm{IOR} / \mathrm{L} / \mathrm{PS} / 12 / 1521$, Indian Legislative Assembly debate, 3 September 1935. 
and wondered if the League 'was to be the court before which niggers, the backward and savage peoples of the world, drag the great nations that revolutionized and transformed mankind?'56 According to historian Giuliano Procacci, such declarations provoked 'feelings and indignation' across the subcontinent. As also reported by the African-American press of the time, Indian public opinion 'bitterly resented Mussolini's statement that whites must be supreme in Africa' and was 'aroused by his charges that the Yellows and the Blacks are united against White supremacy ${ }^{57}$. The interview appeared to 'kick-up a fuss' in Ceylon as well, offending 'the coloristic sensibility of the non-white populations' in the words of the Italian Consul De Pasquale ${ }^{58}$.

\section{Fascist propaganda, Indian nationalism and the press}

In India, it was British ex-missionary and pro-independence activist Charles Freer Andrews who drew public attention to the interview by publishing an outraged article on the matter in the Ahmedabad nationalist newspaper Leader ${ }^{59}$. A close collaborator of Mohandas K. Gandhi and Rabindranath Tagore, Andrews had been involved in international anticolonial and antiracist circles since the 1920s, serving 'as a conduit between South Asian and African-American struggles $^{60}$. The Consul General for Italy in Calcutta, Guido Sollazzo, published a public reply to Andrews' article in the Forward. At the end of the acrimonious exchange of views that followed, Andrews claimed he had 'yet to find a single Indian who does not identify with the sacred cause of Abyssinian freedom as if it were his own'61.

This clash was not unprecedented; on the contrary, the entire atmosphere in that moment was characterized by uneasy and worsening relations between the Italian regime, its diplomatic and consular staff in India, the native press, nationalist circles, and colonial British authorities. At the time, Italian emigrants and their (newly founded or recently 'Fascist-ized') organizations abroad were quite central to the regime's ambitions, envisaged as outposts of its 'spiritual expansion' through propaganda. One aim of this 'cultural diplomacy' abroad was to legitimize the regime's military ambitions and secure a more key position in interwar international relationships by strengthening strategic economic, political and intellectual ties and projecting a new image of the Italian nation ${ }^{62}$. Italian propaganda efforts granted special attention to India as the "hearth of the British empire', a country whose nationalist movement was also showing vulnerability to 'Soviet influence' ${ }^{63}$. To undermine the former and outpace the latter, Italian residents coordinated by Fascist consular offices began to disseminate pro-Axis and anti-British propaganda in India, even broadcasting on the radio in Hindi and $\mathrm{Urdu}^{64}$. Many European and American governments had ceased to view pro-Fascist émigré association-based activities with benevolent tolerance in that period. Rather, governments had become to view it with suspicion when, with the

\footnotetext{
${ }^{56}$ Originally published in the Echo de Paris, then republished in Il Popolo d'Italia, 23 July 1935. B. Mussolini, 'Le mete africane dell'Italia fascista', in Opera Omnia di Benito Mussolini: Dall'inaugurazione della provincia di Littoria alla proclamazione dell'Impero (19 dicembre 1934-9 maggio 1936), eds. E. Susmel and D. Susmel (Firenze: La Fenice, 1959), 106-10 (my translation).

${ }^{57}$ According to the Atlanta Daily World's correspondent from India (4 August 1935), cit. in Kapur, Raising Up a Prophet, 70; for an African-American comment on the interview, see 'Africans Are - Savages Says Premier Mussolini', Chicago Defender, 21 September 1935.

${ }^{58}$ Giuliano Procacci, Dalla parte dell'Etiopia: L'aggressione italiana vista dai movimenti anticolonialisti d'Asia, d'Africa, d'America (Milano: Feltrinelli, 1984), 44-6 (my translation).

${ }^{59}$ Ibid., 44-5; Framke, Delhi-Rom-Berlin, 242-3.

${ }^{60}$ Slate, Colored Cosmopolitanism, 97-101; Kapur, Raising Up a Prophet, 72-8.

${ }^{61}$ Cit. in Procacci, Dalla parte dell'Etiopia, 45-6.

${ }^{62}$ Francesca Cavarocchi, Avanguardie dello spirito: Il fascismo e la propaganda culturale all'estero (Roma: Carrocci, 2010).

${ }^{63}$ Antonino Di Giovanni, 'Giuseppe Tucci, l'IsMEO e gli orientalismi nella politica estera del fascismo', Annali della facoltà di Scienze della formazione 11 (2012): 75-94; Stolte, 'Orienting India', 103-14.

${ }^{64}$ Callum MacDonald, 'Radio Bari: Italian Wireless Propaganda In The Middle East And British Countermeasures 193438', Middle Eastern Studies 13 (1977): 195-207.
} 
unfolding of the Italo-Ethiopian war, these associations rose up in feverish support of the imperial campaign $^{65}$. Italian Fascists in India similarly intensified their efforts in $1935^{66}$. Consul Sollazzo, along with Emilio Benasaglio, the honorary Vice Consul and professor of Italian at the University of Calcutta, were both forced to leave India in 1936 as a result of their propaganda activities in relation to the conflict. In Calcutta, they contributed to publishing the pro-Fascist pamphlet series Italian Community and pressured local editors to have partisan news published on the nationalist press, also in exchange for funding ${ }^{67}$.

Nonetheless, even according to the British, their efforts did not seem to have 'much effect on the press or public opinion in India [...], [which was] still bitterly opposed to Italian policy in Abyssinia' ${ }^{38}$. Indian representatives in the Legislative Assembly condemned pro-Italian propaganda as an 'abuse' that 'ought not to be allowed to any civilized nation' and repeatedly asked for it to be stopped ${ }^{69}$. The Italian residents conversely lamented 'very strong attacks made against Italy and the Italians ${ }^{70}$ and pressed for 'the cessation of the anti-Italian campaign in the Indian newspapers and political groups ${ }^{71}$. Indeed, according to Sollazzo and Benasaglio, 'when the Italian Government decided to take military action against the Ethiopian Empire, the Indian Press started a violent campaign against Italy and the Italians ${ }^{52}$. In the letters and telegrams the two sent to British colonial authorities, they denounced mediatic assaults in which 'history was distorted and even the alliance of Italy with England in the Great War was discarded'73. At the same time, they demanded the authorities take action to censor-printed opinion which 'had lost any sense of measure in judging the attitude of a European Power, who had never done anything wrong to the

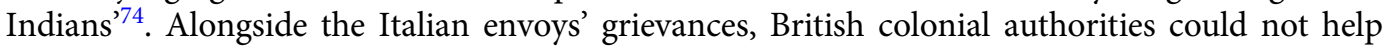
but observe that

[the Indian] Press has devoted much attention to the dispute, both in the news and the editorial columns, and has been vocal in expressing support of Abyssinia and criticism of Italy in terms which have led to protest by the Italian Consul-General. Dispute has been referred to as frankly racial issue, and the view expressed that feelings of other non-European races must be on the side of Abyssinia. There has also been criticism of the vacillation of the League and of the British attitude, which is described as hesitating ${ }^{75}$.

As early as the summer of 1935, the 'attitude of Indian-press papers' had actually proved to be 'one of unanimous and unqualified criticism of Italian policy and the utterances of Mussolini ${ }^{\text {'76. }}$.

\footnotetext{
${ }^{65}$ See the contributions to Il fascismo e gli emigrati, eds. E. Franzina and M. Sanfilippo (Roma-Bari: Laterza, 2003), especially Claudia Baldoli on the anti-British feelings which broke out amongst Italian emigrants in Great Britain during the crisis ('I Fasci in Gran Bretagna', 60-3), and Matteo Pretelli, Il fascismo e gli italiani all'estero (Bologna: CLUEB, 2010), 63-7.

${ }^{66} \mathrm{IOR} / \mathrm{L} / \mathrm{PS} / 12 / 1536$, from FO to J.C. Walton, 2 May 1936; FO, 'Reports on the weekly summary of news; broadcast in Hindustani', 11 April 1936; 'Italy's Latest Propaganda', Daily Telegraph, 14 January 1936. Mario Prayer, 'Italian Fascist Regime and Nationalist India, 1921-45', International Studies 28, no. 3 (1991): 267.

${ }^{67}$ Such as British-educated journalist and editor Asit Krishna Mukherji, with whom Sollazzo planned to launch a pro-Axis monthly journal. IOR/L/PS/12/1536, list of selected pamphlets published on Mukharji Press, Indian Daily News Press, Saraswati Press and Uttara Press, 7 February 1936 drafted by M.K. Johnson, Deputy Commissioner of Police in Calcutta; letters from G. Sollazzo to the Editor of Bishan (Mr. Mukherje) of 6, 22, 26 November and 10, 13, 21 December 1935; 7, 11 January 1936. See also Casolari, In the Shadow, 69.

${ }^{68} \mathrm{IOR} / \mathrm{L} / \mathrm{PS} / 12 / 1536$, from Foreign Secretary to Under Secretary of State for India, 19 March 1936.

${ }^{69} \mathrm{IOR} / \mathrm{L} / \mathrm{PS} / 12 / 1536$, Indian Assembly debates, 31 August, 4 September and 9 September 1936.

${ }^{70} \mathrm{IOR} / \mathrm{L} / \mathrm{PS} / 12 / 1536$, from E. Benasaglio to Chief Secretary to the Government of Bengal, 21 July 1936.

${ }^{71} \mathrm{IOR} / \mathrm{L} / \mathrm{PS} / 12 / 1536$, from G. Sollazzo to G.P. Hogg, Bengal Executive Council, 14 July 1936.

${ }^{72} \mathrm{IOR} / \mathrm{L} / \mathrm{PS} / 12 / 1536$, from E. Benasaglio to Viceroy of India, 27 August 1936.

${ }^{73} \mathrm{IOR} / \mathrm{L} / \mathrm{PS} / 12 / 1536$, from E. Benasaglio to Chief Secretary to the Government of Bengal, 21 July 1936.

${ }^{74} \mathrm{IOR} / \mathrm{L} / \mathrm{PS} / 12 / 1536$, from G. Sollazzo to G.P. Hogg, 14 July 1936.

${ }^{75} \mathrm{IOR} / \mathrm{L} / \mathrm{PS} / 12 / 1536$, from IPD to Secretary of State for India (India Secretary), 3 August 1935.

${ }^{76} \mathrm{IOR} / \mathrm{L} / \mathrm{PS} / 12 / 1536$, from India Secretary to IPD, 31 August 1935.
} 
'Remarkable strength and unanimity of public feeling' manifested in the form of an 'entirely spontaneous' 'colour feeling' ${ }^{\text {'7 }}$. An overview of the nationalist press confirms this general impression: the editor of the Bombay-based Indian Social Reformer, Swaminath Natarajan, was engaged in a correspondence with Du Bois in those same years and expressing an interest in 'the present day Negro opinion ${ }^{78}$. Between 1934 and 1936, the newspaper dedicated a dense series of articles to the 'Italian Aggression on Abyssinia', the connection between 'American Negroes and the Ethiopian Struggle' (understood as a 'Race Issue') and the role of Europe and the League ${ }^{79}$. The same occurred on the frontpages of the Hindustan Review ('The Coloured Peoples and Abyssinia'; 'The Romance of Abyssinia') ${ }^{80}$, the Indian Review ${ }^{81}$, the Allahabad Twentieth Century ${ }^{82}$ and the Calcutta-based journal Modern Review - which had covered African-American politics since the early twentieth century ${ }^{83}$. A variety of issues captured Indian interest, for example, the Madras-based Tamil and Hindi magazine of the Women's Indian Association, Stri-Dharma, published an article on the 'Abyssinian Women Ready to Fight for the Empress in the Coming War'84 while other papers reported that 'Italy Bombs and Gases Innocent Abyssinians ${ }^{\text {'85 }}$. The proceedings of the debates held at the Legislative Assembly and calls for 'Abyssinian solidarity days' were also published ${ }^{86}$. Eventually, the Secretary of State for India accused this Indian press of being 'uncontrolled' to the extent that it 'increases the difficulties in the way of attempted interference by the Government of India ${ }^{87}$ :

In India, on account of the colour feeling which the Abyssinian business is sure to arouse, it is less likely that the Indian Press will keep within bounds, and in any restraining action that the Government of India might take they would run the risk of incurring unpopularity and being dubbed pro-Italian ${ }^{88}$.

${ }^{77} \mathrm{IOR} / \mathrm{L} / \mathrm{PS} / 12 / 1536$, from J.C. Walton to A. Warner, FO, 28 August 1935.

${ }^{78}$ UMAL/MS 312, from Indian Social Reformer to Du Bois, 2 October 1936.

${ }^{79}$ About thirty articles in the issues 45 (1934), 46 (1935) and 49 (1938).

${ }^{80}$ Hindustan Review 67, October 1935.

${ }^{81}$ M.K. Nambyar, 'League and Abyssinian Crisis'; K.K. Sharma, 'Italy and Abyssinia Burma and India; The Italo-Abyssinian War'; Singha Sasadar, 'The Abyssinian Conflict'; Abdul Ghafur, 'Italy, Abyssinia and Islam', Indian Review 36 (1935).

${ }^{82}$ P.R. Ramchandra Rao, 'The Italian Conquest of Ethiopia', July 1935; Lanka Sundaram, 'Abyssinia, India and the League', October 1935; D.S. Gordon, 'Conflict of Interests in Abyssinia', December 1935.

${ }^{83}$ 'Italy and Abyssinia', Modern Review 57 (1935); 'Foreign Periodicals: Ethiopia: the Newest Theatre of War; Britain, France and Italy to Partition Ethiopia?', 'British Labour Leader on the Ethiopian Question', 'Italo-abyssinian Conflict', 'The Mohmands and Ethiopians', Subhas Chandra Bose, 'The Secret of Abyssinia and Its Lesson', 'Abolition of Slavery in Abyssinia', 'Abyssinia Refutes Italian Attack', 'Ancient India and Abyssinia', 'German, Japanese and British Interests in Abyssinia', 'Italy and Abyssinia', 'Occidental 'Neutrality' in the Italo-Abyssinian Dispute', Modern Review 58 (1935); 'Foreign Periodicals: Literature in Abyssinia', 'The Abyssinian Constitution and Slavery', 'Abyssinia's Past Neglect', 'France's Complicity in Italo-abyssinian War', 'Heroism of the Abyssinians', 'Italo-Abyssinian War', 'Foreign Periodicals: Proud Ethiopia', 'Foreign Periodicals: The War from the Ethiopian Point of View', Modern Review 59 (1936); Nancy Cunard, 'The Betrayal of Ethiopia', 'Address to the Ethiopian Emperor on Behalf of Indians', 'Ethiopian Resistance Not Yet Broken', D. Graham Pole, 'The Rape of Abyssinia', 'League of Nations Undecided Over Abyssinia', Modern Review 60 (1936); 'Indian Periodicals: The Emperor of Ethiopia', Modern Review 62 (1937); 'Abyssinian Emperor's Hope Against Hope', 'Congress Working Committee on Italian Savagery and Tyranny in Abyssinia', 'De Jure and De Facto Recognition of Italian Conquest of Abyssinia', 'Massacre of Abyssinians by Italians', 'Empress of Ethiopia's Tearful Appeal', Modern Review 61 (1937); 'Rebellion in Abyssinia', Modern Review 63 (1938). The coverage of Italian difficulties in 'pacificating' Ethiopia went on until 1940.

${ }^{84}$ Stri-Dharma 18, August-September 1935; see also Michelle E. Tusan, 'Writing stri dharma: International feminism, nationalist politics, and women's press advocacy in late colonial India', Women's History Review 12, no. 4 (2003): 623-49.

${ }^{85}$ Modern Review 60 (1936). See also the debates examined in Framke, Delhi-Rom-Berlin, 249-57.

${ }^{86}$ 'The Council of State: Italian Aggression in Abyssinia', 'Proceedings of the Council: Sympathy For Abyssinia'; 'Proceedings of the Council: Abyssinia Day', 'Conferences: Sympathy for Abyssinia', Indian Annual Register 36, JanuaryJune 1936; Fred Barrie, 'Ethiopian Days', India Monthly Magazine 16, February 1936.

${ }^{87} \mathrm{IOR} / \mathrm{L} / \mathrm{PS} / 12 / 1536$, from Secretary to Consul General for Italy in Calcutta, 6 September 1935; from India Secretary to IPD, 31 August 1935.

${ }^{88} \mathrm{IOR} / \mathrm{L} / \mathrm{PS} / 12 / 1536$, from J.C. Walton to A. Warner, 28 August 1935. 
In the following months, this perception of wholesale Indian opposition to the Italian occupation was such that even the important Gujarati firm G. M. Mohamedally \& Co. was expelled from Ethiopia on the charge of having 'assisted in the assassination attempt against the Viceroy Graziani', an allegation based on the 'propaganda that has been allowed to circulate against the firm' and the latter's open support for Ethiopians during the $\operatorname{war}^{89}$.

The impact of the Italian invasion on Indian public opinion has thus been pinpointed as a moment of rupture after which it became more difficult for the Fascist regime to establish a fruitful collaboration with South Asian actors ${ }^{90}$. As mentioned above with respect to Italian residents in India, the regime had been actively pursuing such collaboration since the mid-1920s, in part through efforts of 'cultural penetration' and intellectual propaganda addressed to nationalist political circles. From today's perspective, scholars of global fascism have come to regard European regimes' influence over and connections with Hindutva organizations as the greatest indicator that these regimes' oriental policies were successful ${ }^{91}$. However, it should also be noted that the regime's attempts to build dialogue also found fruitful ground amongst INC personalities or radical actors motivated by 'enemy of my enemy' logics and admiration for Italy's recent inde-

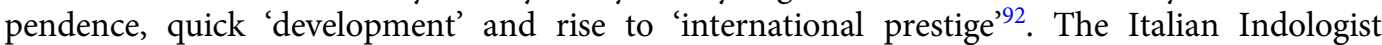
Giuseppe Tucci stood out for his ability to establish relations with the Bengali intelligentsia revolving around the pan-Asianist Greater India Society and Tagore's Visva-Bharati University ${ }^{93}$. While Gandhi (1931) and Tagore $(1925,1926)$ had visited Rome, and the former's brief meeting with Mussolini had been loudly publicized by the regime, it was Congress leader Subhas Chandra Bose (who stayed in the Italian capital in 1934-35 and 1937) who welcomed Mussolini's proposals as beneficial for Indian liberation and regularly cooperated with Axis powers ${ }^{94}$.

In 1936, Mussolini's ministers also attempted to set up a meeting with Jawaharlal Nehru on the belief that 'through his mediation, large sections of Indian public opinion would abandon their anti-Italian stance on the Abyssinian affair', but Nehru refused ${ }^{95}$. Instead, he reconnected with the LAI during a stay in London (February-March 1936) where he was 'called upon [...] to raise awareness in India of the Abyssinia crisis'. Thereafter, he committed to steering INC opinion on the matter and made it one of the key aims of his anti-imperialist and anticolonial campaign over the year. In public speeches and articles, he denounced the Italian war on Ethiopia as exemplifying the 'predatorily imperialist' nature of Fascism. Stressing the latter's interest in

\footnotetext{
${ }^{89}$ Cit. in Dominique Harre, 'The Indian Firm G. M. Mohamedally \& Co in Ethiopia (1886-1937)', Annales d'Ethiopie 30, no. 1 (2015): 296. The New Times and Ethiopia News, a journal edited by the British communist Sylvia Pankhurst in support of Ethiopia, reported a similar story. Apparently, a 'Bombay Indian merchant who had a chain of stores in Abyssinia had been expelled with [...] the confiscation of his stores' by the Italian occupiers. The motivation behind his expulsion was so quoted by the Fascist newspaper Giornale d'Italia: 'he acted as a secret agent for the British Intelligence Service'. 'Italy's Anti-British Propaganda', 15 May 1937.

${ }^{90}$ Historian Marzia Casolari even argues that 'before the Ethiopian crisis, there were no tensions toward Italy from Indian public opinion or the British authorities', but rather 'public reactions [ . . . ] came to the fore only after the Italian invasion'. In the Shadow, 59; see also Di Giovanni, 'Giuseppe Tucci', 82; Prayer, 'Italian Fascist Regime', 265; Kapur, Raising Up a Prophet, 8; Stolte, Orienting India, 104, 115.

${ }^{91}$ Notably, the paramilitary Rashtriya Swayamsewak Sangh (1925-) and Hindu Mahasabha (1915-). Marzia Casolari, 'Hindutva's Foreign Tie-Up in the 1930s: Archival Evidence', Economic and Political Weekly 35, no. 4 (2000): 218-28. For a broader reflection, see B. Zachariah, 'Rethinking (the Absence of) Fascism in India, c. 1922-45' in Cosmopolitan Thought Zones, 213-35.

${ }^{92}$ Giorgio Borsa and Beonio-Brocchieri, Garibaldi, Mazzini e il Risorgimento nel risveglio dell'Asia e dell'Africa (Milano: FrancoAngeli, 1984). A well-known example is the Bengali intellectual Taraknath Das, who went from being one of the founders of the revolutionary Ghadar movement to becoming a scholar and 'cultural cooperator' of Italian Fascism and German Nazism. Maria Framke, 'Shopping Ideologies for Independent India? Taraknath Das's engagement with Italian Fascism and German National Socialism', Itinerario 40, no. 1 (2016): 55-81.

${ }^{93}$ Stolte, Orienting India, 83-114.

${ }^{94}$ Valdo Ferretti, 'L'India, Gandhi e il Fascismo', Rivista degli studi orientali 62, no. 1-4 (1988): 109-18; Renzo De Felice, Il fascismo e l'Oriente. Arabi, ebrei e indiani nella politica di Mussolini (Bologna: Il Mulino, 1988), 187-244.

${ }^{95}$ Prayer, 'Italian Fascist Regime', 265.
} 
economically exploiting its African empire, Nehru asserted a 'common bond' between Ethiopia and India, another 'victim of imperialist greed'96. According to 'Nehruvian anti-Fascism', Fascism and Western imperialism 'were blood brothers' and to oppose 'Berlin, Rome and Tokyo' meant also opposing the British, whose foreign policy was appeasing and supporting Fascism in Europe as well as in Asia ${ }^{97}$. This anti-imperialist line was then reinforced by the outbreak of the SinoJapanese war (1937). This convergence set up anti-Fascism as a pivot point for the very possibility of articulating internationalist solidarities in the area and resulted in the Congress expressing 'heartfelt' support for China ${ }^{98}$. Furthermore, it inspired Nehru's pronunciations on the Spanish Civil War, his visit to Barcelona in 1938, and the INC's move to organize an Indian Aid Spain campaign in contestation of the British non-intervention policy and support of the Republican front ${ }^{99}$.

Nevertheless, it is important to specify that Nehru never framed his internationalist vision or his commitment to Indian liberation in racial terms, not even after his mid-1930s stay in London when he was welcomed into the city's lively pan-Africanist circles. Rather, he outlined a rhetoric of anti-imperialism founded on the 'primary dimensions' of nation and class ${ }^{100}$. Ambivalence characterized Gandhi's position as well. In August 1935, the British and African-American press reported that Gandhi had called for contributions to put together an 'Indian Red Cross contingent for Ethiopia', arousing African-American enthusiasm by allegedly stating that 'India cannot ignore Benito Mussolini's threat against colored people'101. Gandhi went on to disclaim this statement, however, denying that he had taken part in fundraising for Ethiopia and repeatedly refusing to take a public stand in 1935. While even Tagore described himself as 'deeply shaken' by the Italian aggression ${ }^{102}$, it was again Bose who worked 'to bring about a pro-Italian reorientation of some sections of the Indian Press (Forward, The Statesman, Advance...)' in its aftermath, describing the invasion 'as a reaction to British imperialism'; the same endeavour was then carried forward by Monindra Mohan Moulik, Secretary of the Indian Press Association of Calcutta and a pupil of Tucci ${ }^{103}$.

\section{Abyssinian Days, citizens' meetings and anticolonialism 'from below'}

Having addressed institutional and intellectual debates, I now turn to the observations of historians who have emphasized the 'generalized' and 'popular' character of the Hands Off Ethiopia campaign in most of its manifestations ${ }^{104}$. As evidenced by their research, it is only by considering

\footnotetext{
${ }^{96}$ Louro, Comrades against Imperialism, 203-5; Padmalata Sharma, Indian Reaction to Fascism and Nazism (New Delhi: Radha, 1994), 41-54; M. Framke, 'The 1930s in India as a Formative Period', in The Non-Aligned Movement and the Cold War: Delhi-Bandung-Belgrade, eds. N. Mišković, H. Fischer-Tiné and N. Leimgruber (London: Routledge, 2014), 37-56.

${ }^{97}$ William F. Kuracina, 'Colonial India and External Affairs: Relating Indian Nationalism to Global Politics', Journal of Asian and Africa Studies, 42, no. 6 (2007): 521; Benjamin Zachariah, Nehru (New York: Routledge, 2004), 94-107; Sarvepalli Gopal, Jawaharlal Nehru: A Biography. Vol. 1 1889-1947 (Bombay: Oxford University Press, 1976), 232-7.

${ }^{98}$ Maria Framke, 'Encounters with Fascism and National Socialism in non-European Regions', Südasien Chronik 2 (2012): 351; Id., "We Must Send a Gift Worthy of India and the Congress!” War and political humanitarianism in late colonial South Asia', Modern Asian Studies 51, no. 6 (2017): 1969-98.

${ }^{99}$ Id., 'Political Humanitarianism in the 1930s: Indian aid for Republican Spain', European Review of History 23, no. 3 (2016): 63-81; Michael P. Ortiz, 'Spain! Why? Jawaharlal Nehru, Non-Intervention, and the Spanish Civil War', European History Quarterly 49, no. 3 (2019): 445-66. Nehru's report of his visit to Spain to the Congress concluded: 'any victory over Fascism, no matter where it takes place - is of help to the people of India'. Nancy Cunard, 'Negro Writers and Hindoo Leaders Against Fascism', New Times and Ethiopia News, 23 July 1938.

${ }^{100}$ Louro, Comrades against Imperialism, 198-205.

${ }^{101 '}$ 'Duce Offends India: Call for Red Cross Aid for Abyssinia', Daily Telegraph, 26 July 1935; other articles from the AfricanAmerican press in Kapur, Raising Up a Prophet, 69.

${ }^{102}$ Procacci, Dalla parte dell'Etiopia, 48-58.

${ }^{103}$ Ferretti, 'L'India, Gandhi e il Fascismo', 111; Casolari, In the Shadow, 63; Prayer, 'Italian Fascist Regime', 262.

${ }^{104}$ Fronczak, 'Local People's', 246; Munro, 'Ethiopia Stretches Forth', 38; Gebrekidan, 'In Defense of Ethiopia', 146.
} 
the movement's diverse composition and permeability to local claims that we can account for its transnational reach. In relation to South Asia, this approach offers the opportunity to build on the authoritative claim that 'the historiography of Indian nationalism has for a long time been dominated by elitism ${ }^{\prime 105}$. To extend the implications of this argument to the study of internationalist mobilizations, we must enlarge our gaze to include significant working-class or outcast contributions and pay greater heed to ideological heterogeneity and geographical diversity. Moreover, just as the 1935-36 protests entailed a full range of agitational practices worldwide - from rallies and petition-signing to spontaneous mass gatherings, boycotts, vandalistic 'flash actions', riots and street fights - the same is true for various areas of the subcontinent where anti-Fascist demonstrations, citizens' meetings and boycotts took place.

The earliest protests coming to the attention of the British and African-American press were those held in the former capital. Here, 'huge gatherings of Calcutta citizens, Hindu and Moslem condemned the attitude of Italy to Abyssinia and regretted the inability of the "Imperialist Powers" to keep the peace'. 'References on the part of both Mussolini and Hitler that black men are barbarians' had 'sharpened' Indian feelings, with the result that 'harsh comment of Fascism and Hitlerism was made in the speeches' on these occasions (July and November 1935) ${ }^{106}$. Summer protests were also fuelled by news that 'local workers were being enrolled to fight in Eastern Africa'107. The first gathering, the 'public meeting of the citizens of Calcutta' held on 26 July 1935, passed a resolution condemning the imperialist threat offered by Italy to Abyssinian independence and [appreciating] the heroic efforts of the Abyssinian people to remain free'. The lengthy declaration as published in the Negro Worker concluded

This meeting [ ... ] calls upon the people of India to organize protest meetings and demonstrations against the aggression of Italian imperialism, and at the same time calls upon the workers and peasants of Italy to resist the fascist move of the Italian Government, and thereby strengthen the fight against Fascism, War, Imperialism. It further calls upon the Indian people to cease commercial relations with Italy as a retaliatory measure ${ }^{108}$.

Again in Calcutta, the Indian Congress Socialist Party (1934-48), a leftwing group active within the INC, convened a meeting on the same issue, during which a

[...] unanimous resolution was passed to hold further meetings in which Italian policy would be condemned, position taken by Abyssinia appreciated and assurance given of moral support from India. Suggestion was also made that Italian workers and peasants should take advantage of the situation to foment civil war in Italy and overturn fascist regime. Commercial boycott of Italy by Indian merchants was also suggested ${ }^{109}$.

Boycotts of Italian goods did indeed take place throughout India alongside the 'Abyssinian solidarity days' held in multiple Indian urban centres on 1 September $1935^{110}$. In some cases, these events were promoted by 'Indian socialists', and socialists also organized protests in front of the Bombay Italian Consulate in the days following the invasion. Massive demonstrations were called by the communist All India Trade Union Congress on 27 October 1935 and by socialist members of the INC on 11 November. Nehru then proclaimed an 'Abyssinian day' in Allahabad on 5 May

\footnotetext{
${ }^{105}$ Ranajit Guha, 'On Some Aspects of the Historiography of Colonial India', in Subaltern Studies I: Writings on South Asian History \& Society (Delhi: Oxford University Press, 1982), 1.

106“Anti-Italian Feeling in India', Times, 29 July 1935; 'Il Duce's War In Ethiopia Has Repercussions - Indians Turbulent', Chicago Defender, 5 November 1935; 'Solidarity with Ethiopia - The colonies - India', Negro Worker, June-July 1935.

${ }^{107}$ Procacci, Dalla parte dell'Etiopia, 47.

${ }^{108}$ 'Indian Opinion on the Italo-Abyssinian Conflict', Negro Worker, December 1935.

${ }^{109} \mathrm{IOR} / \mathrm{L} / \mathrm{PS} / 12 / 1536$, from IPD to India Secretary, 3 August 1935.

${ }^{110}$ See the analysis of the daily Amrita Bazar Patrika in Stolte, Orienting India, 114.
} 
1936 (birthdate of the Fascist Empire), followed by demonstrations in the main centres during the next four days; these protests were defined by the Italian Consul Sollazzo as 'the funeral of Abyssinia' ${ }^{\prime 11}$. The larger context surrounding these initiatives was a global wave of anti-Italian boycotts and sabotages involving colonial labour in African, American and European port towns, with dockworkers refusing to work on Italian ships and consumers being called on to eschew Italian goods ${ }^{12}$. 'Abyssinian days' and 'weeks' were launched, for example, at the beginning of November 1935 by the Gold Coast section of the West African Youth League and Nigerian Youth Movement, paralleled by the Indian and Afro-Caribbean union unrest in the British West Indies ${ }^{113}$.

A considerable number of letters sent by heads of Indian local assemblies to British authorities also attest to the pervasiveness of this outbreak of anti-Italian indignation. The President of the C.U. Committee of Engandiyoor (Kerala, South India) was among the first, alerting the Viceroy of India that a 'monster [sic] gathering of the citizens of Enagudiyur and the surrounding villages (Malabar)' had passed the following resolution on 12 September 1935:

This meeting strongly disapproves of the threatening attitude of Italy towards Abyssinia and prays that the Government of India may be pleased to do everything within their power to safeguard the independence of Abyssinia and the peace of the world ${ }^{114}$.

In the same month, the Chicago Defender reported that a similar motion in 'emphatic protest against Mussolini's attitude and to convey to the Ethiopian Emperor the sympathy of the people of India' was passed in Bombay by the Imperial Indian Citizenship Association (1915- $)^{115}$.

An impressive number of meetings were then held in the Tamil Nadu state, South India. At the time, the public space of Tamil Nadu was permeated by the rising importance of the Congress and a multiplicity of radical popular movements ${ }^{116}$. The local anti-caste political mobilizations there are worth recalling as their claims indicate the extent to which South Asian understandings of race, racism and racial solidarity were interwoven with the preeminence of dharma in societal interactions and political structures.

Since the late eighteenth century, European comparative philologist, Sanskrit-speaking pandits of Brahman origins and British administrators had collaborated in creating 'dialogical constructions' supporting then-prevailing configurations of caste, tribal and community groupings. The theorization of an Indo-European linguistic family helped give rise to the notion of an 'IndoEuropean idea'. According to this notion, Indian upper-caste Brahmins were descended from the 'civilized' and 'light-skinned' Aryan Sanskrit-speaking tribes that had invaded the subcontinent from Central Asia (2000-1400 BCE), while the 'black aboriginal tribes' that inhabited the Indus Valley and spoke Dravidian and Munda languages, later forced to move southward, were

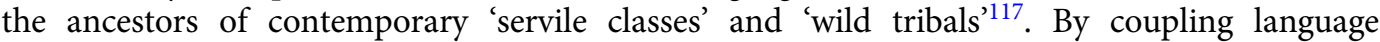

\footnotetext{
${ }^{111}$ Procacci, Dalla parte dell'Etiopia, 47, 63-64.

${ }^{112 ‘}$ African Natives Would Help Fight for Ethiopians', Baltimore Afro American, 2 November 1935; Fronczak, 'Local People's', 261; Robinson, 'The African diaspora', 62.

${ }^{113}$ 'West African Youth League', Negro Worker, December 1935; Asante, Pan-African Protest, 136; Weisbord, 'British West Indian', 36.

${ }^{114} \mathrm{IOR} / \mathrm{L} / \mathrm{PS} / 12 / 1536$, from V.P. Raman, President of the C.U. Committee of Engaudiyur, to Viceroy of India, 17 September 1935.

${ }^{115}$ An organization originally founded to demand a status for Indians equal to subjects in British Dominions and other colonies. 'Indians Protests Against Mussolini', Chicago Defender, 27 September 1935. Niraja Gopal Jayal, Citizenship and its Discontents: An Indian History (Cambridge: Harvard University Press, 2013), 28.

${ }^{116}$ J. Racine, 'Caste and Beyond in Tamil Politics', in Rise of Plebeians? The Changing Face of the Indian Legislative Assemblies, eds. C. Jaffrelot and S. Kumar (London: Routledge, 2009), 440-42; David Arnold, The Congress in Tamilnad: Nationalist Politics in South India, 1919-1937 (London: Routledge, 1977).

${ }^{117}$ Thomas R. Trautmann, Aryans and British India (New Delhi: Yoda Press, 2004), 164-205; S. Bayly, Caste and Race in Colonial Ethnography of India, in The Concept of Race, 165-218.
} 
classifications to racial types with the help of anthropometric measures such as complexion ranking, upper-caste Hindus were able to posit a 'sign of kinship' with the colonizer and distance themselves from "'domestic others" (Muslims, aboriginal groups, Dalits, and "criminal" tribes) as well as inferior "foreign others" (anchored at bottom by dark-skinned Africans)"118. In the early twentieth century, egalitarian mobilizations in southern and western India appropriated and reversed these racial and ethnolinguistic categories to extend bonds of solidarity across lower-caste groups and beyond barriers of endogamy. In Maharashtra, the Satyashodak Samaj (1873-) founded under the Bombay presidency by Jyotirao Phule had already denounced Brahaminist societal organization and exclusionary cultural practices as foreign imports imposed by the Aryan 'invaders' on the 'original people' of India, people that the Aryans had 'enslaved and divided'119. This framing gained influence over the 1920s-1930s development of 'anti-Brahmin' Maratha-dominated movements in the region, and especially so in Tamil Nadu. Under the Madras presidency, demands for lower-caste education, employment and representation asserted an alternative 'Dravidian' Tamil identity to support their claims ${ }^{120}$. Just as Phule had framed the experience of low-caste Indians as analogous to the history of African-American slavery ${ }^{121}$, the leader of the anti-elitist Self-Respect [Suyamariyathai] League (1926-) E.V. Ramaswami Naicker (known as Periyar) compared the former to the condition of Blacks in colonial South Africa ${ }^{122}$. These arguments were later taken up again by more recent 'transnationally oriented' anti-caste political movements such as the Dalit Panthers (1972-, Bombay), an organization modelled on the Black Panther Party (1966-82, Oakland $)^{123}$. Focusing on the interwar years, such internationalist interest in antiracist struggles of this kind could help account for the unparalleled local concentration of protests held across Tamil Nadu in 1935-36 proclaiming unconditional solidarity with the Ethiopian people.

On 11 October 1935, the Municipal Council of Vellore (Tamil Nadu) had already assembled to condemn 'the action of the Italians in their aggressive unwarranted invasion of Abyssinia' and to 'request the British Government to effectively and promptly help Abyssinia in pursuance of the decision of the League of Nations at Geneva for the sake of the Indian people struggling in a sad plight there'124. Similarly, the Commissioner of Dharapuram Municipality (Tamil Nadu) sent the Government of Madras a resolution passed on 17 October 'condemning the action of Italy in having declared War without any reason against Abyssinia'. The Municipal Council requested 'the British Government to relieve the distress of Indians affected by the war in Abyssinia' and thus 'to suppress Italy which has broken the league covenant and to help Abyssinia'125. A few months later, the citizens of Salem (Tamil Nadu) renewed this demand: expressing their 'deep sympathy with

\footnotetext{
${ }^{118} \mathrm{Basu}$, 'The Dialectics of Resistance', 53; Krishna, 'A postcolonial racial/spatial', 141. These debates appear to have been familiar to some of these Afrodiasporic interlocutors, and the latter occasionally entered into them in a polemical manner UMAL/MS 312, W.E.B. Du Bois, India and Africa, 1931, typed draft; Indians and American Negroes, ca. March 1936, typed draft.

${ }^{119} \mathrm{C}$. Jaffrelot, 'The uneven emancipation of the lower castes', in India's Silent Revolution: The Rise of the Lower Castes in North India, ed. Id. (London: Hurst \& Co, 2003), 152-5, 171; Gail Omvedt, 'Jotirao Phule and the Ideology of Social Revolution in India', Economic and Political Weekly 6, no. 37 (1971): 1972.

${ }^{120}$ M.S.S. Pandian, 'Notes on the Transformation of 'Dravidian' Ideology: Tamilnadu, c. 1900-1940', Social Scientist 22, no. 5/6 (1994): 84-104.

${ }^{121}$ Which he had learned about at a Scottish Mission school in Pune and through American antiracist literature. Jaffrelot, 'The uneven emancipation', 153; Immerwahr, 'Caste or colony?', 279.

${ }^{122}$ Mohan Ram, 'Ramaswami Naicker and the Dravidian Movement', Economic and Political Weekly 9, no. 6-7-8 (1974): 217-24; E. Annamalai, The Political Rise of Tamil in the Dravidian Movement in South India, in Handbook of Language and Ethnic Identity, eds. J. Fishman and O. Garcia (Oxford: Oxford University Press, 2011), 230-41; Jaffrelot, The uneven emancipation, 171.

${ }^{123}$ Also claiming historical ties with the African diaspora, the Dalit Panthers responded to a need for global visibility, the urgency of which was still reportedly manifested at an institutional level during the 2001 Durban World Conference against Racism. At the conference, demands to discuss casteism were rejected by the Indian government on the grounds that it should be considered a purely domestic issue. Vijay Prashad, 'Afro-Dalits of the Earth, Unite!', African Studies Review 43 (2000): 190-3.

${ }^{124} \mathrm{IOR} / \mathrm{L} / \mathrm{PS} / 12 / 1536$, from Chairman of the Municipal Council of Vellore to Government of Madras, 11 October 1935.

${ }^{125} \mathrm{IOR} / \mathrm{L} / \mathrm{PS} / 12 / 1536$, from Commissioner of the Dharapuram Municipality to Government of Madras, 24 October 1935.
} 
the people of Abyssinia in their hours of distress', they called 'upon the Government of India to withdraw from the League in the case an honourable settlement is not made in respect of the Independence of Abyssinia'126. Finally, in May 1936, the District Board of the district of Tiruvannamalai (Tamil Nadu) met to 'condemn the barbarous method employed by Italy in fighting Abyssinians and convey its sympathy to the Abyssinians and their Emperor', further condemning 'the attitude of the League of Nations in not taking timely action to prevent the war' and requesting 'the Government of India to withdraw from the League'127.

\section{Italian 'Islamic policy' and Indian Muslims' internationalist anti-Fascism}

To return to northern cities, antiwar demonstrations held right after the invasion were led by 'Muslim personalities' in Calcutta (27 July 1935) and the Muslim population of Karachi (today Pakistan $)^{128}$. A general meeting representing the local Muslim community was then held in Delhi on 25 October 1935. Its final statement condemned the summary executions of Muslim religious chiefs ordered by 'the Italian Government of Somali-land', defining them as 'unjust', and alluded to 'a danger to the life of those Italian inhabitants in India, who are daily distributing pamphlets in defence of their country's action against Abyssinia' if the government of India should fail to 'convey the message to the Italian Government ${ }^{\prime 29}$.

Any account of South Asian participation in the Hands Off Ethiopia campaign must consider the objections expressed by Indian Muslims, apparently amongst the most vocal of all critics. In an effort to avoid homologizing assumptions, it should be noted that the majority of Muslim supporters of the Ethiopian cause in India were militants and groups deriving from the internationalist pan-Islamic Khilafat movement (1919-24). Indeed, the most vociferous were sectors of Indian Muslim politics dominated by this traditional political partner of the INC; as indicated above, with some notable exceptions, this organization mainly shared an anti-Fascist reading of the crisis. Nonetheless, various actors expressed coherent stances against Italian colonial policies. This is particularly meaningful given that Fascist propaganda efforts targeted in particular the Muslim population in India as in other colonial areas. Such efforts were driven by Italian aspirations to use East Africa as a starting point to expand into the Middle East, an imperial enterprise that required weakening its British and French rivals, already under pressure from nationalist movements ${ }^{130}$. The 'Islam policy of Italy' in the Middle East sought to spread the word that 'the Duce, Benito Mussolini, loves Muslems and orientals and he has a sincere desire to lift them

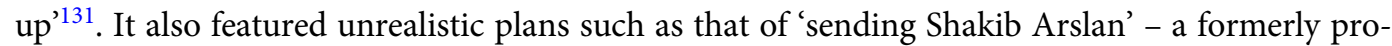
Ottoman and pan-Islamic Lebanese leader who had turned towards the Axis in the 1930s and spoken out in favour of the occupation of Ethiopia ${ }^{132}$ - 'to India to try to persuade the

\footnotetext{
${ }^{126} \mathrm{IOR} / \mathrm{L} / \mathrm{PS} / 12 / 1536$, from V. R. Sundararaju Chettiar, President of the meeting of the Citizens of Salem, to IDP, 10 May 1936.

${ }^{127} \mathrm{IOR} / \mathrm{L} / \mathrm{PS} / 12 / 1536$, from M. Shanmuga Mudalier, President of the Tiruvannamalai District, to IDP, 16 June 1936.

${ }^{128}$ Procacci, Dalla parte dell'Etiopia, 47.

${ }^{129} \mathrm{IOR} / \mathrm{L} / \mathrm{PS} / 12 / 1536$, from M. S. Inayat Nashin to Viceroy of India, 27 October 1935.

${ }^{130} \mathrm{Nir}$ Arielli, 'Beyond “Mare Nostrum”. Ambitions and Limitations in Fascist Italy's Middle Eastern Policy', Geschichte und Gesellschaft 37, no. 3 (2011): 385-407; Manuela Williams, 'Mussolini's Secret War in the Mediterranean and the Middle East: Italian Intelligence and the British Response', Intelligence and National Security 22, no. 6 (2007): 881-904; Anna Baldinetti, 'Fascist Propaganda in the Maghrib', Geschichte und Gesellschaft 37, no. 3 (2011): 408-36.

${ }^{131} \mathrm{IOR} / \mathrm{L} / \mathrm{PS} / 12 / 2151$, translation of extract from Corriere Hararino (original in Arabic), 21 April 1937.

${ }^{132}$ Alejandro Colás, 'Internationalism in the Mediterranean, 1918-1942', The Journal of North African Studies 1, no. 3 (1996): 211-33; Anna Baldinetti, The Origins of the Libyan Nation: Colonial Legacy, Exile and the Emergence of a New Nation-State (London: Routledge, 2013), 101. According to historian Haggai Erlich, Arslan's pro-fascist propaganda met with opposition from most of the Arab and pan-Arabist literati and journalists who commented on it and also provoked reactions from the Islamic community of Addis Ababa as evidenced by discussions in the local Amharic press. 'Haile Sellassie and the Arabs, 1935-1936', Northeast African Studies 1, no. 1 (1994): 47-61.
} 
Moslems there that Italy will free their brother Moslems in the Mediterranean from British domination' ${ }^{\prime 33}$.

Despite the diffusion of geographically bound and separatist ideologies, Indian Muslim leaders and scholars had contributed greatly to formulating a political vision of pan-Islamic solidarity since at least the Russo-Ottoman war (1877-78) and gained an influential voice in its 'universal call to action' ${ }^{\prime 34}$. Moreover, the Khilafat movement had quite recently used 'the threat of widespread Muslim agitation' as a 'more common means of persuasion' against the British or in favour of the Ottoman caliphate ${ }^{135}$. British intelligence, busy combatting an alleged 'pan-Islamic menace' to imperial security and heading off the possibility that it joins forces with Axis powers ${ }^{136}$, thus began to worry about Muslim India's response to Fascism. Intelligence officers were especially concerned about 'the particular Moslem reaction' to the Abyssinian crisis, wondering about its differences from 'the general Indian' opinion ${ }^{137}$. The alarm was explained as follows: 'Italian propaganda' was not having 'much success locally [in East Africa], but the reason for this do [sic] not apply abroad' in that 'Moslem populations outside Ethiopia [...], in Egypt, Arabia, Syria and India, who have no opportunity to compare Italian speeches with Italian acts, have been misled by Italian propaganda'138. Also in 1938, British envoys in Ethiopia were engaged in anxious discussions about the hundreds of Ethiopians and Eritreans leaving for all-expenses-paid pilgrimages to Mecca 'organized throughout by the Italian authorities'. Eventually, the Under-Secretary of State for India was warned that the Hajj - 'a great success' of 'considerable [...] value as propaganda' - was soon to also involve 'Indian Moslems who refused to go this year, although invited to do so by the [Italian] Government' since these Muslims were now proposing 'to take advantage of a similar opportunity if it is offered from next year' ${ }^{139}$.

However, despite 'Italian propaganda to win Muslim opinion, on the grounds that conquest by Italy might relieve Abyssinian Muslims from the Christian yoke', British colonial authorities in India came to agree that 'Muslim opinion was on the side of Abyssinia'140. Indeed, 'prominence was given by the Muslim press to the view that the Emperor deserves Muslim support in return for asylum given by Negus of Abyssinia to Muslim refugees from Mecca in the earliest days of Islam'141. In this case, just as popular interpretations of Psalms 68:31 ('Princes shall come out of Egypt, Ethiopia shall soon stretch out her hands unto God') were feeding pan-African responses

\footnotetext{
${ }^{133} \mathrm{IOR} / \mathrm{L} / \mathrm{PS} / 12 / 2151$, from E. Drummond to British Consul-General in Milan, 17 December 1936.

${ }^{134} \mathrm{C}$. Jaffrelot and L. Louër, 'The Gulf-South Asia Religious Connections: Indo-Islamic Civilization vs. pan-Islamism?' in Pan-Islamic Connections, ed. Id. (Oxford: Oxford University Press, 2017), 14-7; Azmi Özcan, Pan-Islamism: Indian Muslims, the Ottomans and Britain (1877-1924) (Leiden: Brill, 1997); Cemil Aydin, 'Imperial Paradoxes: A Caliphate for Subaltern Muslims', ReOrient 1, no. 2 (2016): 171-91.

${ }^{135}$ Conor Meleady, 'Negotiating the caliphate: British responses to pan-Islamic appeals, 1914-1924', Middle Eastern Studies 52, no. 2 (2016): 184, 190.

${ }^{136}$ John Ferris, “'The Internationalism of Islam”: The British Perception of a Muslim Menace, 1840-1951', Intelligence and National Security 24, no.1 (2009): 57-77.

${ }^{137} \mathrm{IOR} / \mathrm{L} / \mathrm{PS} / 12 / 1536$, from India Secretary to IPD, 31 July 1935.

${ }^{138} \mathrm{IOR} / \mathrm{L} / \mathrm{PS} / 12 / 2151$, from T. Vikeley, British Consul in Harar, to Chargé d'Affaires of British Legation in Addis Ababa, 20 December 1936.

${ }^{139}$ IOR/L/PS/12/2151, from D.M.H. Riches, British Consul in Harar, to British Consulate-General in Addis Ababa, 29 April 1938. Regarding 'pro-Muslim' fascist policies in Ethiopia, see Robertson, 'Race as a Factor', 52-3. Mussolini was not the only Fascist leader to engage with the Hajj for propaganda purposes: in 1937, the Spanish dictator Francisco Franco also sponsored a pilgrimage to Mecca. Eric Calderwood, 'Franco's Hajj: Moroccan Pilgrims, Spanish Fascism, and the Unexpected Journeys of Modern Arabic Literature', PMLA 132, no. 5 (2017): 1097-116.

${ }^{140} \mathrm{IOR} / \mathrm{L} / \mathrm{PS} / 12 / 1536$, from George Clerk (British ambassador in France) to Government of India, summarized in the minutes 'Abyssinia. Indian Opinion', IPD, 22 August 1935.

${ }^{141} \mathrm{IOR} / \mathrm{L} / \mathrm{PS} / 12 / 1536$, from IPD to India Secretary, 3 August 1935. Nonetheless, Italian propaganda was publicized also on sections of the Muslim press. According to the Lahore Truth, 'a [Muslim] Lahore weekly, for instance, publishes about one article a week to create a favourable atmosphere for Italy's rape of Abyssinia and the "civilizing" work she is doing in that unfortunate land, closing its eyes to the systematic persecution and suppression of the Muslims of Abyssinia'. 'Fascist Propaganda in India', New Times and Ethiopia News, 21 August 1937.
} 
to the Italo-Ethiopian conflict in Christian Africa and the Americas ${ }^{142}$, another scriptural reading supported Muslim solidarity: the account in which the Prophet instructs his earliest followers (the Sahabah, fleeing anti-pagan prosecution in Mecca) to ask for asylum from the Christian Negus of al-Habasha (Ethiopia) and the Ethiopians' welcoming of these refugees. This 615-616 episode had 'continued to resonate among Muslims across centuries'143 and it was taken up by mid-1930s Islamic scholars writing about Ethiopia ${ }^{144}$ as well as the Ethiopian emperor. Indeed, the emperor quoted from the Qu'ran to warn there might be 'a general uprising throughout the Moslem world $[\ldots]$ if Great Britain, France and other powers do not prevent Italy declaring war on Ethiopia'145.

Despite commonly being identified with the Orthodox Tewahedo Church, the Ethiopian state has always hosted a significant Muslim population. It was this community to which Selassie (rather ambiguously) appealed when Mussolini threatened to invade, making concessions and unprecedentedly presenting himself as 'the emperor of all black people ${ }^{\text {'146. }}$. Ethiopian diplomats and dignitaries also appear to have been 'well aware of the importance of winning support in the Arab [and Muslim] world', above all due to their being located in the Horn of Africa. This awareness is evidenced for instance by the fact that Hakim Warqnah, the Ethiopian Minister in London, sought to revive the memory of 'Italian atrocities in Tripoli ${ }^{147}$. In fact, to locate these discussions in context we must recall the antecedents that had made Italian Fascism an issue for pan-Islamic activists and groups even before the Ethiopian campaign. One of these was the last phase of the so-called 'Pacification of Libya', the 'Reconquest of Cyrenaica' (1928-32), another outsized colonial campaign employing the same genocidal tactics later deployed in Ethiopia. This campaign and, notably, the public hanging of Sanusi leader Omar alMukhtār, provoked outrage throughout the Islamic and Arab world, bringing the 'popularity' of the Fascist regime to its lowest point ever ${ }^{148}$. According to contemporary accounts, the hostility triggered by these events was so great that 'the horrors of the conquest of Cyrenaica' were not likely to be forgotten. For example, political scientist Elizabeth Monroe describes hearing them 'mentioned by Ulemas in Algeria, by the Destour in Tunisia, by a taxi driver in Syria, and with quivering hatred by one or two Egyptians' ${ }^{149}$. The 'internationalization of the Libyan issue' had already involved Muslim India through anti-Italian boycotts, the sending of volunteers and demonstrations ('Libya days') organized across North Africa, the Middle East and migrant networks in Europe ${ }^{150}$.

In 1935, appeals to Muslim solidarity with Ethiopia revived these intercolonial anti-Fascist feelings. Such renewed opposition ranged from the divided opinions expressed in the Syrian, Palestinian and Iraqi press to the campaign organized by Étoile Nord-Africaine, the Sanusi opposition in Cyrenaica, and campaigns in Turkey, Syria and Sudan to send aid and/or volunteers ${ }^{151}$. Although discussions in

\footnotetext{
${ }^{142}$ Shilliam, 'Intervention and colonial-modernity'.

${ }^{143}$ Haggai Erlich, Islam and Christianity in the Horn of Africa: Somalia, Ethiopia, Sudan (London: Lynne Rienner, 2019), 1-2.

${ }^{144}$ Richard Pankhurst, 'Ethiopia and Tripoli: Harkim Warqnah's Condemnation of Italian Action in Tripoli in 1911: Ethiopian Authorship of a Now-Forgotten Pamphlet', International Journal of Ethiopian Studies 6, no. 1-2 (2012): 193.

${ }^{145 ‘}$ 'Moslems May Aid Ethiopia If War Comes’, Plaindealer, 5 July 1935.

${ }^{146}$ Haggai Erlich, Saudi Arabia and Ethiopia: Islam, Christianity, and Politics Entwined (London: Lynne Rienner, 2007), 42-3.

${ }^{147}$ Pankhurst, 'Ethiopia and Tripoli', 187-93.

${ }^{148}$ Ali Abdullatif Ahmida, 'When the Subaltern Speak: Memory of Genocide in Colonial Libya 1929 to 1933', Italian Studies 61 (2006): 175-90.

${ }^{149}$ Elizabeth Monroe, The Mediterranean in Politics (London: Oxford University Press, 1938), 168, quoted in J. Wright, 'Mussolini, Libya, and the Sword of Islam' in Ben-Ghiat, Fuller, Italian Colonialism, 125.

${ }^{150}$ Ulrike Freitag and Israel Gershoni, 'The Politics of Memory: The Necessity for Historical Investigation into Arab Responses to Fascism and Nazism', Geschichte und Gesellschaft 37, no. 3 (2011): 330; Baldinetti, The Origins, 69-105; Saïd Mestiri, Moncef Bey: Le règne (Tunis: Arcs Editions, 1988), 168; Procacci, Dalla parte dell'Etiopia, 68; Cemil Aydin, The Idea of the Muslim World: A Global Intellectual History (Cambridge: Cambridge University Press, 2017), 159.

${ }^{151}$ Fronczak, 'Local People's', 257; Erlich, Islam and Christianity, 137; Id., Saudi Arabia and Ethiopia, 42-65; Jonathan Derrick, Africa's 'Agitators': Militant Anti-Colonialism in Africa and the West, 1918-1939 (London: Hurst\&Co, 2008), 332-45; Rabah Aissaoui, 'Algerian nationalists in the French political arena and beyond: the Etoile nord-africaine and the Parti du peuple algérien in interwar France', The Journal of North African Studies 15, no.1 (2010): 8-9; Baldinetti, The Origins, 66, 101-4.
} 
most Arab countries about taking a stand on Ethiopia did not overlook its status as a 'neighboring Christian, African, and Eastern state', recent scholarship has argued that they often evolved into antiimperialist stances against Italian Fascism despite these differences ${ }^{152}$. Further evidence is provided by the international press. For instance, the Chicago Defender interview with the Rifian exiled revolutionary Abd el-Krim pointed to a Moroccan interest in the conflict (October 1935) ${ }^{153}$. According to the Addis Ababa correspondent for the Times, the prevailing sentiment was 'that the Emperor's appeal to Moslem loyalty may gain sympathy far outside the Ethiopian frontiers, and that the attitude of Egypt and the Levant may have some influence ${ }^{154}$. Indeed, Egypt acted on the basis of its historical links with Ethiopia and position in pan-Islamic networks to send volunteers and aid while also hosting a lively and complex debate on forms of fascism ${ }^{155}$. Despite circulating widely, Italian propaganda appears to have had less and less success in Egypt as well since 'the story of the drastic methods used by Italy in Libya' was 'too fresh in Egyptian minds, and the presence of numerous Tripolitan refugees' apparently kept 'these memories alive' ${ }^{156}$. According to Italian authorities themselves, in fact, the pro-Italy campaign carried out by Fascist envoys on the occasion of the Abyssinian crisis 'aroused unjustified alarms and ill-concealed hostility until [reaching as far as] Egyptian government circles ${ }^{157}$. In India, even the British noted that 'counter-Italian propaganda in Urdu and Persian was not much needed since [... ] at any rate there is little disposition to be impressed with the Italians' and 'no danger of Italian atrocities in Libya and Abyssinia being forgotten ${ }^{158}$.

To conclude, the unambiguous stance taken on the matter by Maulana Shaukat Ali, former main figure of the pro-Ottoman Khilafat movement, illustrates the ties between anti-Fascist pro-Ethiopia sentiments and the historical background of Muslim internationalism in South Asia ${ }^{159}$. Before the outbreak of the war, the ex-pan-Islamic leader announced in front of the Legislative Assembly that

If the people of Abyssinia, who are under-dogs, are being treated disgracefully, and are to be trampled down, then it is the duty of India to send out, not one hundred soldiers, but ten divisions, if necessary; and if the Government ask for money, I hope I will be one who will persuade all of my friends and the whole of India to sanction all the money and men needed to serve this noble country.

\footnotetext{
${ }^{152}$ Haggai Erlich, 'The Tiger and the Lion: Fascism and Ethiopia in Arab Eyes', in Arab responses to fascism and Nazism: Attraction and Repulsion, ed. I. Gershoni (Austin: University of Texas Press, 2014), 171-288; Id., 'Identity and Church: Ethiopian-Egyptian Dialogue, 1924-59', International Journal of Middle East Studies 32, no. 1 (2000): 29.

${ }^{153 ' M o r o c c o ~ R e b e l ~ U n e a s y ~ I n ~ H i s ~ I s l a n d ~ E x i l e ~-~ A b d-E l-K r i m ~ I s ~ A n x i o u s ~ T o ~ G e t ~ I n t o ~ W a r ~ A g a i n s t ~-~ E x i l e d ~ R i f f ~ H e a r s ~ O f ~}$ Fighting In Ethiopia', Chicago Defender, 26 October 1935.

${ }^{154}$ 'Moslem Sympathy with Ethiopia: Offers of Help from the Levant', Times, 8 August 1935.

${ }^{155}$ Haggai Erlich, The Cross and the River: Ethiopia, Egypt, and the Nile (London: Lynne Rienner Publishers, 2002), 104-12; Id., 'Egypt, Ethiopia and the Abyssinian Crisis, 1935-1936', in The Nile - Histories, Cultures, Myths, eds. Id. and I. Gershoni (Boulder: Lynne Rienner, 2000), 183-98; 'Moslems to Give Aid to Ethiopians', Chicago Defender, 28 September 1935. Regarding Egypt and Fascism, see Israel Gershoni and James Jankowski, eds., Confronting Fascism in Egypt: Dictatorship versus Democracy in the 1930s (Stanford: Stanford University Press, 2010).

${ }^{156} \mathrm{IOR} / \mathrm{L} / \mathrm{PS} / 12 / 2151$, from British Embassy in Cairo to A. Eden, 25 March 1937. Moreover, as recounted by Claude McKay during his Moroccan years, the 'native boycott of Italian business' that 'spread all through North Africa' in 1935 had started in Egypt. 'Native Liberation Might Have Stopped the Franco Revolt', New Leader, 18 February 1939.

${ }^{157} \mathrm{IOR} / \mathrm{L} / \mathrm{PS} / 12 / 2151$, 'La Politique Islamique de l'Italie', extract quoted in a letter from FO to India Under-Secretary, 14 April 1937. Regarding the pan-Islamic ties between the All-India Muslim League and Wafd Party, see Noor-Aiman I. Khan, Egyptian-Indian nationalist collaboration and the British Empire (London: Palgrave Macmillan, 2011).

${ }^{158} \mathrm{IOR} / \mathrm{L} / \mathrm{PS} / 12 / 2151$, from IO to G.T. Fisher, 2 October 1937; from FO to J.P. Gibson, 21 October 1937.

${ }^{159}$ M. Raisur Rahman, 'The Mahatma and the Maulana: Understanding Minority Politics in British India', Rivista di Studi Sudasiatici 2 (2007): 57-84; Syed Tanvir Wasti, 'The Circles of Maulana Mohamed Ali', Middle Eastern Studies 38, no. 4 (2002): 51-62. Even African-American and Afro-Caribbean pan-Africanists regarded the Khilafat as an exemplary case of Hindu-Muslim unity due to his partnership with Gandhi's Non-cooperation project. M. Naeem Qureshi, Pan-Islam in British Indian Politics: A Study of the Khilafat Movement, 1918-1924 (Leiden: Brill, 1999); Slate, Colored Cosmopolitanism, 46-7, 54-7.
} 
He closed by declaring himself 'very glad to offer to be a soldier and work in that army that goes to defend the weak and the oppressed and fight unjust people out to rob others of liberty, hearth and house $^{160}$. Towards the end of the conflict, another discussion of 'Indian feelings regarding Italy's Conquest of Abyssinia' was called by the pan-Islamic leader of the Muslim Nationalist Party Mohammad Asaf Ali (likewise a pro-Ottoman activist in the 1910s and later member of INC) and Ali did not hesitate in expressing his heartfelt grievances about this cause ${ }^{161}$. Still in 1937, the Pashtun anticolonial activist and INC Muslim leader Abdul Ghaffar Khan was organizing antiFascist mass meetings in Calcutta and Peshawar. At these protests, 'fiery speeches' were made 'denouncing the Italians and resolutions adopted declaring Mussolini an imposter and an enemy of Islam'162.

\section{Conclusion}

The 'historical, political, organizational and ideological meanings and implications' of the Hands Off Ethiopia campaign for the African continent and diaspora has been under investigation since the early $1970 \mathrm{~s}^{163}$. This article attempted to contribute to the debate with an understanding of such mobilization also as a generative moment for Afro-Asian solidarity. As it argued, the South Asian participation in the transnational protests against the Italian invasion of the Ethiopian Empire was widespread. Far from being an isolated episode, it was the outcome of years of dialogue and collaboration: at the outbreak of the Italo-Ethiopian war, the Indian public had been reading on anti-Black racism, slavery and segregation since the mid-nineteenth century and nationalist leaders were discussing the evils of global White supremacy with Black activists and intellectuals on multiple platforms. The open-endedness of these seminal encounters as well as the political, religious and cultural heterogeneity of the Indian subcontinent were reflected in the mobilization. Indeed, protestors motivated their support for Ethiopia in very different ways: they called upon the INC's anticolonial programme, Islamic internationalism, egalitarian anti-casteism and, above all, diffuse anti-racist feelings of Afro-Asian solidarity. More than simply expressing solidarity with the Ethiopian people, South Asian protestors actively contributed to the increasingly harsh criticisms moved by colonial and non-White opinions (ranging from the African-American radical press to Syrian intellectual circles) to the authoritarian projects launched by fascist governments. These intercolonial dialogues kept the memory of the brutality of Italy's colonial ventures alive and framed fascisms as the other face of 'European capitalism' ${ }^{164}$. Therefore, they fostered the growing Indian scepticism towards the Italian regime's attempts to present itself as an emancipatory alternative to the yoke of the British Empire. While European interwar leftwing politics was increasingly struggling to combine anticolonial opposition with the urgency of antiFascist resistance ${ }^{165}$, sections of the South Asian public appeared not to suffer from this problematic estrangement. Instead, the outrage caused by the 'rape of Abyssinia ${ }^{166}$ provided new and powerful mobilizing arguments against both Fascist propagandists and British colonial rulers.

\footnotetext{
${ }^{160} \mathrm{IOR} / \mathrm{L} / \mathrm{PS} / 12 / 1521$, Indian Legislative Assembly debate, 3 September 1935.

${ }^{161} \mathrm{IOR} / \mathrm{L} / \mathrm{PS} / 12 / 1536$, Indian Legislative Assembly debate, 11 September 1936.

${ }^{162 ‘}$ 'Well Done, Moslems! A Snub to Mussolini', New Times and Ethiopia News, 17 July 1937.

${ }^{163}$ Robinson, 'The African diaspora', 52.

${ }^{164} \mathrm{IOR} / \mathrm{L} / \mathrm{PS} / 12 / 1521$, Indian Legislative Assembly debate, 3 September 1935.

${ }^{165}$ Neelam Srivastava, 'Anti-colonialism and the Italian Left: Resistances to the Fascist Invasion of Ethiopia', Interventions 8 , no. 3 (2006): 414; Buchanan, 'The Dark Millions', 653-62.

${ }^{166}$ 'Fascist Propaganda in India', New Times and Ethiopia News, 21 August 1937.
}

Cite this article: Buelli A. 2023. The Hands Off Ethiopia campaign, racial solidarities and intercolonial antifascism in South Asia (1935-36). Journal of Global History 18: 47-67, doi:10.1017/S1740022822000092 